Check for updates

Cite this: RSC Adv., 2017, 7, 20995

Received 31st January 2017 Accepted 30th March 2017

DOI: $10.1039 / \mathrm{c} 7 \mathrm{ra01310h}$

rsc.li/rsc-advances

\section{Silicic acid condensation under the influence of water-soluble polymers: from biology to new materials}

\author{
Vadim V. Annenkov, (D) *a Elena N. Danilovtseva, ${ }^{a}$ Viktor A. Pal'shin, ${ }^{a}$ \\ Ol'ga N. Verkhozina, ${ }^{a}$ Stanislav N. Zelinskiy ${ }^{a}$ and Uma Maheswari Krishnan ${ }^{b}$
}

\begin{abstract}
Silicon is among the most abundant elements on the Earth. It occurs in many minerals and plays an important role in several biochemical processes. Some living organisms use silicon dioxide as a substrate for building elements of their bodies. Unicellular diatom algae build frustules from silicon dioxide. The skeleton of siliceous sponges is a silicaprotein composite. Similarly, rice hulls which protect seeds, contain silica as an important component. The living organisms assimilate silicon from the environment in the form of silicic acid. However, the biochemical mechanisms involved in the transformation of silicic acid to solid siliceous materials are still poorly understood. Evidently, condensation of silicic acid in the living organisms proceeds under control of biopolymers and it is important to know how various types of polymers influence the condensation. Bio-inspired chemistry involving the interaction between polymeric silicic acid and functional polymers results in interesting composite materials, including nanoparticles and bulk materials. This review contains a brief description of the mechanism of silicic acid condensation in aqueous medium and also includes a discussion on various precursors of silicic acid. The main focus of the review is on the influence of polymers bearing nitrogen and oxygen-containing functional groups on silicic acid condensation starting from monomer to three-dimensional polymer. Influence of molecular weight of the organic polymer on the condensation and structure of the resulting product is also elaborated. The biological importance of the obtained data and strategies for novel applications of the synthesized composite materials are described in the concluding section of the review. The biomimetic condensation processes open up new vistas for development of novel materials and applications in the biomedical and process industries.
\end{abstract}

${ }^{a}$ Limnological Institute of the Siberian Branch of the Russian Academy of Sciences, 3, Ulan-Batorskaya St., P.O. Box 278, Irkutsk, 664033, Russia.E-mail: annenkov@lin. irk.ru; annenkov@yahoo.com; Tel: +7-9148982577
${ }^{b}$ Centre for Nanotechnology \& Advanced Biomaterials (CeNTAB), School of Chemical and Biotechnology, SASTRA University, Thanjavur - 613401, Tamil Nadu, India

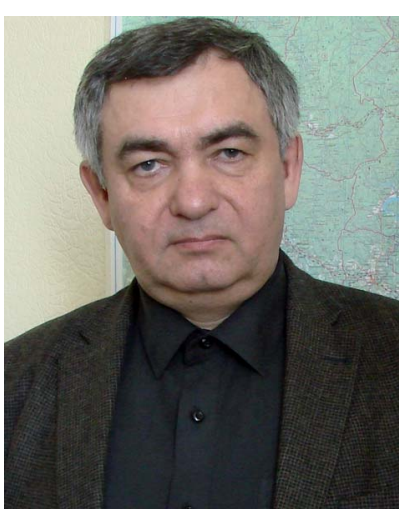

Vadim Annenkov was graduated from Irkutsk State University, Russia, in 1984. He received Ph.D. in Macromolecular Science from Irkutsk Institute of Chemistry in 1989 and D.Sc. degree from Irkutsk State University in 2001. He is a Deputy Director of the Limnological Institute SB RAS, Irkutsk, Russia. He has near 120 scientific papers and 18 patents. Research interests include synthesis and properties of hydrophilic polymers; physical chemistry of polymer solutions; mathematical simulation of macromolecular systems; study of the molecular mechanisms of biomineralization; biomimetic methods for nanoparticles synthesis; design systems for immune and genetic diagnosis.

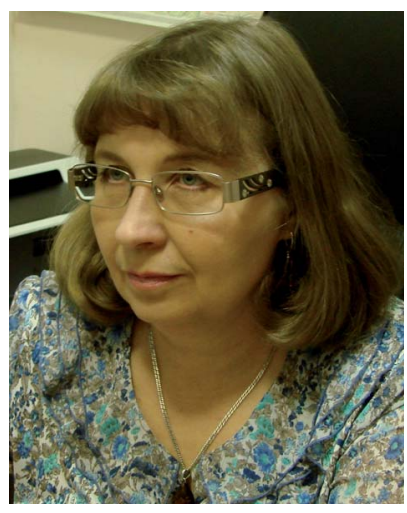

Elena Danilovtseva was graduated from the Department of Chemistry, Irkutsk State University, Russia in 1984. She received her Ph.D. in Macromolecular Science from the Institute of Chemical Sciences, Almaty, Kazakstan in 1991. She is a Senior researcher in Limnological Institute SB RAS, Irkutsk, Russia. She is author of near 75 scientific papers and 12 patents. Her scientific interests include synthesis and properties of water-soluble polymers; complexes of polymers with metal ions and oxide particles; molecular mechanisms of biosilicification; biomimetic methods for the preparation of nanoparticles and hybrid materials; design of functionalized coatings. 


\section{Introduction}

Silicon is among the most abundant elements on the Earth, it occurs in many minerals and plays an important role in biochemical processes. Some living organisms use silicon dioxide as a structural material in their bodies. ${ }^{1}$ Diatom algae are unicellular organisms which provide more than $20 \%$ of photosynthetic oxygen and contribute to a corresponding amount of primary organic production. ${ }^{2}$ The diatom cell lives in a "glass house" ${ }^{3}$ - siliceous frustule built from silicon dioxide in a form similar to molten quartz glass (Fig. 1A). Sponges belong to a class of ancient and interesting invertebrates which play an important role in ecosystems as filtering organisms. They also serve as a residence for an enormous number of symbionts. Sponge bodies are inexhaustible source of biologically active compounds. ${ }^{4}$ Siliceous sponges represent more than $90 \%$ of sponges ${ }^{5}$ and their skeleton is based on siliceous spicules composite needle-like constructions (Fig. 1B). Rice (Oryza sativa)

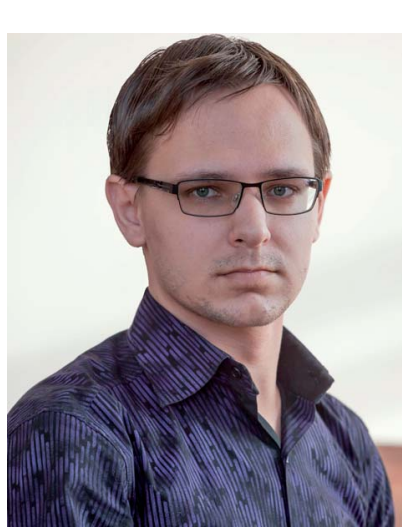

Viktor Pal'shin was graduated from the Department of Chemistry, Irkutsk State University, Russia in 2008. He received his Ph.D. in Macromolecular Science from the Institute of Problems of Chemical Physics, Chernogolovka, Russia in 2012. He is a researcher in Limnological Institute SB RAS, Irkutsk, Russia. He is the author of 7 scientific articles and 1 patent. Scientific interests: synthesis and properties of organo-silica nanoparticles; colloidal systems; biosilicification; dynamic and static light scattering. is a staple crop consumed predominantly by the Asian population. It has been found that the xylem sap in these plants are rich in silicic acid. The role of silicon in augmenting disease resistance, ${ }^{6}$ chlorophyll a content and growth ${ }^{7}$ of rice plants has been demonstrated by different research groups. Silica deposits have been found in the cell walls of rice plants and it has been postulated that these silica deposits enhance the stability of the cell wall structure during mitotic cell division. ${ }^{8}$ Similarly, silicon deposits have also been identified in the stomata of rice plants and it is believed that these deposits tend to reduce water loss through transpiration. ${ }^{9}$ The nano-dimensional silica particles in rice are believed to be formed using hemi-cellulose callose as a template..$^{10}$ Biogenic silica and composites are a great challenge to material science specialists because these materials are highly ordered at various levels and a lot of them, e.g. diatom frustules consists of a material similar to melting quartz glass ${ }^{11}$ which artificial analogs are produced at temperatures above $1000{ }^{\circ} \mathrm{C}$ only. Siliceous organisms put many questions to biologists and biochemists: how living organisms capture silicon from the environment? How they store and transport silicon in their bodies? How they build highly ordered constructions from silicon dioxide without high temperatures and hazardous chemicals?

Silicon is present in natural water mainly in the form of monomeric silicic acid. Evidently, transformation of $\mathrm{Si}(\mathrm{OH})_{4}$ to solid $\mathrm{SiO}_{2}$ or siliceous composites proceeds through condensation in the presence of some organic substances, probably biopolymers. The nature and action mechanism of these substances is yet not thoroughly deciphered. The main approach to discovering novel biosilicification agents involves isolation and separation of organic substances from biosilica, structure identification, study of silicification activity using in vitro models, monitoring the transformation of the molecule of interest in the organism and finally formulation of the hypothesis on the mechanism of biosilicification. This strategy had resulted in the discovery of

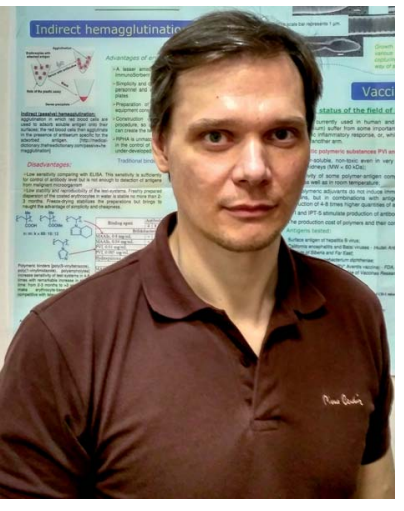

Stanislav Zelinskiy was graduated from the Department of Chemistry, Irkutsk State University, Russia in 1998. He received his Ph.D. in Catalysis from the Irkutsk State University in 2002. He is a researcher in Limnological Institute SB RAS, Irkutsk, Russia. He is author of 25 scientific articles and 5 patents. His scientific interests include synthesis, structure and reactivity of organic compounds; metal-complex catalysis; synthesis of fluorescent dyes and labels.

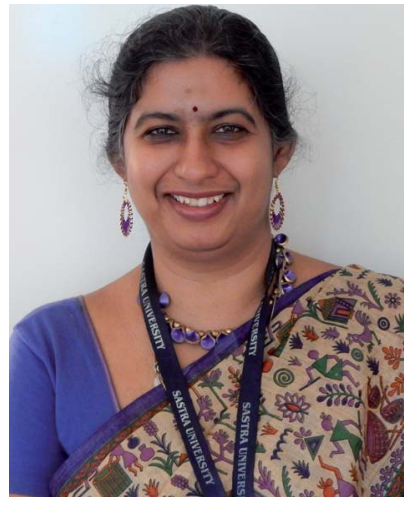

Uma Maheswari Krishnan is a Professor at the Centre for Nanotechnology and Advanced Biomaterials (CeNTAB) and School of Chemical and Biotechnology, SASTRA University, India. She received Ph.D. degree in Applied Chemistry from Bharathiar University, India in 2000 and has postdoctoral experience from the Southwestern Medical Centre, University of Texas, USA. She received training on thin film processing and clean room processes at University of Arkansas, USA. In 2003 she joined as a Lecturer at SASTRA University and is currently the Associate Dean of Bioengineering and Chemistry. Her research interests include smart drug delivery systems, nanobiosensors, electrophysiology and mesoporous materials. She has about 150 publications in these areas. 

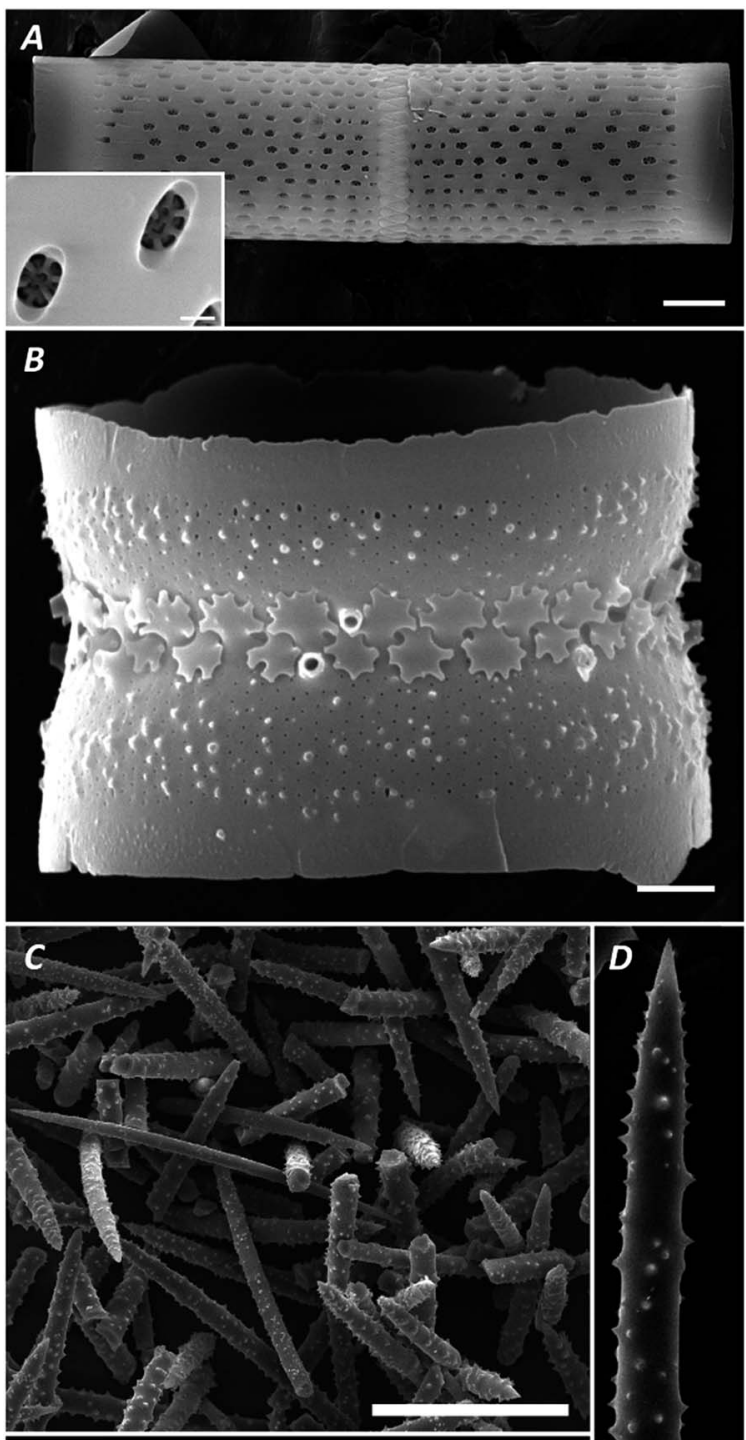

$E$

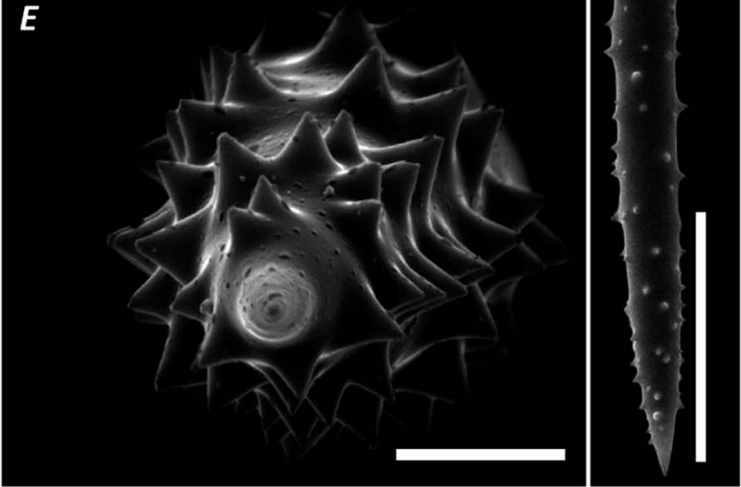

Fig. 1 Siliceous valves of diatoms Aulacoseira baicalensis (K. I. Meyer) Simonsen (A), Stephanodiscus meyeri Genkal \& Popovskaya (B) and spicules of sponge Lubomirskia baicalensis (Pallas, 1773) (B). Scale bar represents 5 (A, E), 0.5 (A, insertion), 1 (B), 100 (C) and 50 (D) $\mu \mathrm{m}$.

silaffins - proteins with phosphate and polyamine posttranslation modifications ${ }^{12,13}$ and silicateins - proteins capable of catalyzing hydrolysis of Si-O-C bonds. ${ }^{14}$ The growing interest in biosilicification during the last few decades has resulted in concerted research efforts devoted to aqueous phase silicic acid condensation in the presence of organic polymers bearing functional groups similar to groups in the hypothesized natural silicification agents. Such studies have at least two objectives - to understand biological processes with simpler and available models and to obtain new bioinspired material, including nanoparticles and bulk composites with the intricate and complex morphologies commonly encountered in the biological systems.

This review summarizes information about $\mathrm{Si}(\mathrm{OH})_{4}$ condensation in aqueous medium in the presence of oligomeric or polymeric molecules capable of interacting with monomeric or polymeric silicic acid. Biological importance and possible applications of these materials are also discussed. Siliceous materials are intensively studied in various fields and we limit this review with water-based systems where free silicic acid is evidently present and plays an important role.

\section{Precursors of silicic acid}

Silicic acid is not stable in the free state and hence it is produced in situ from various precursors. The most simple and cheap precursors are inorganic silicates like sodium, potassium silicates and liquid glasses of variable composition, e.g. $\mathrm{Na}_{2} \mathrm{O} \cdot x \mathrm{SiO}_{2} \cdot{ }^{15}$ Silicic acid is a very weak acid $\left(\mathrm{p} K_{\mathrm{a}}=9.7-9.9\right)^{16,17}$ and addition of acid to a solution of inorganic silicates results in formation of $\mathrm{Si}(\mathrm{OH})_{4}$. The other convenient way to obtain silicic acid from inorganic silicates is through the action of cation-exchange resin in $\mathrm{H}$-form. This procedure facilitates the formation of $\mathrm{Si}(\mathrm{OH})_{4}$ solution free from inorganic salts. Siliceous sols were prepared by acidification of sodium silicate solution with $\mathrm{HCl}(\mathrm{pH}=1-2)$ following with action of a cation-exchange resin which removes $\mathrm{Na}^{+}$ions. ${ }^{18}$ The obtained solutions were not analyzed and it seems that monomeric silicic acid is the main component of these solutions because $\mathrm{Si}(\mathrm{OH})_{4}$ is stable in acidic area. ${ }^{19}$

There are also several organic derivatives of silicic acid which are easily hydrolyzable in aqueous medium. Tetramethyl orthosilicate $\mathrm{Si}(\mathrm{OMe})_{4}(\mathrm{TMOS})$ interacts with water and gives rise to silicic acid and methanol in approximately ten seconds. TMOS is usually added to $1-2 \mathrm{mM} \mathrm{HCl} \mathrm{solution} \mathrm{which} \mathrm{prevents}$ $\mathrm{Si}(\mathrm{OH})_{4}$ from condensation during hydrolysis. ${ }^{20,21}$

Silicon catecholate salts are obtained by the reaction between 1,2-dihydroxybenzene (catechol) salt and tetraethyl orthosilicate (TEOS). ${ }^{22}$ These compounds are readily hydrolysable at neutral $\mathrm{pH}$ values as shown below:

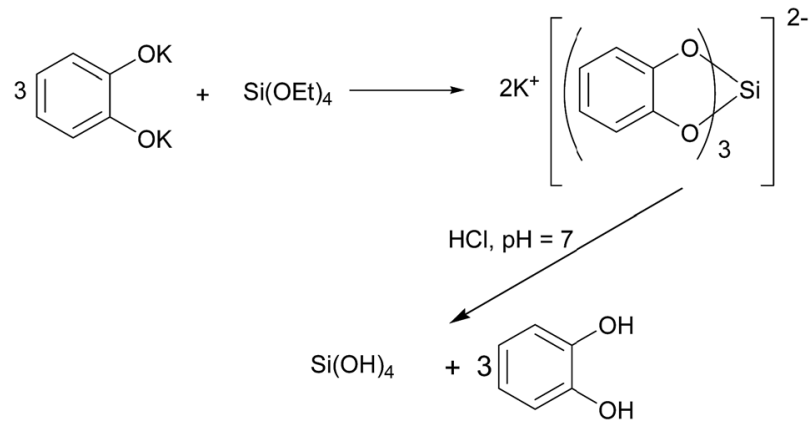


The first study on silicon catecholate salt hydrolysis ${ }^{23}$ showed that the concentration of the complex reduces from $50 \mathrm{mM}$ to 20-28 mM during the first $2 \mathrm{~min}$ of the reaction and these levels remained virtually unaltered even after $24 \mathrm{~h}$. These data however are in contradiction with the results ${ }^{24}$ reported for potassium silicon catecholate salt (K2-SiKat) which showed a decrease of K2-SiKat concentration from $30 \mathrm{mM}$ to $0.1-$ $0.7 \mathrm{mM}$ immediately after the $\mathrm{pH}$ was adjusted to 7 .

Tetrakis(2-hydroxyethyl)orthosilicate (THEOS) was obtained by the reaction between TMOS and ethylene glycol ${ }^{25}$ as follows:

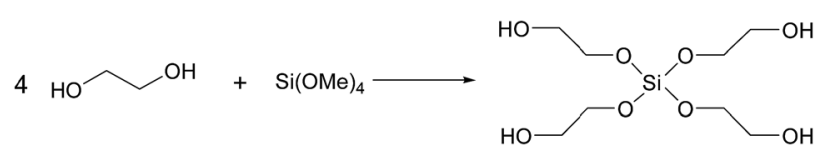

This is a water soluble compound which on hydrolysis gives rise to silicic acid. THEOS was recommended as the precursor for synthesis of unshrinkable silica gels in aqueous medium. ${ }^{26}$ There is however, no information about the hydrolysis rate for THEOS and hence participation of partially hydrolyzed forms in the condensation reaction cannot be excluded.

Inorganic silicates produce silicic acid immediately after neutralization with acid and the only byproduct formed is inorganic salt, e.g. NaCl. Hence these compounds are most suitable for study of mechanism of silicic acid condensation and for simulating biochemical reactions. On the other hand, the fast hydrolysis rate and alkaline nature of the silicates complicates experiments and can result in irreproducibility. Organic precursors do not have these disadvantages and can be applied for design of siliceous materials. But the stepwise hydrolysis and formation of organic byproducts decrease the utility of these compounds to serve as precursors of $\mathrm{Si}(\mathrm{OH})_{4}$.

\section{Silicic acid condensation in aqueous medium}

Condensation of silicic acid has been extensively studied for many decades and it is described in several books and reviews. ${ }^{19,27-31}$ We describe here the main peculiarities of the reaction in aqueous medium.

Silicate ions $\mathrm{SiO}_{4}{ }^{4-}$ are stable at high $\mathrm{pH}$ values but at $\mathrm{pH} 13$ formation of oligosilicate particles containing several silicon atoms was observed. ${ }^{32}$ The condensation proceeds as a nucleophilic substitution reaction $\left(\mathrm{S}_{\mathrm{N}} 2\right)$ between $\sim \mathrm{Si}-\mathrm{OH}$ and $\sim \mathrm{Si}-\mathrm{O}^{-}$ moieties through a pentacoordinated transition state: ${ }^{27,33-37}$

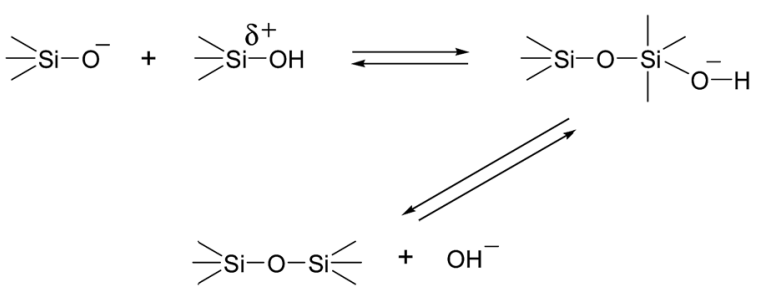

This reaction requires ionized silanol and neutral $\sim \mathrm{Si}-\mathrm{OH}$ groups. The first ionization constant of $\mathrm{Si}(\mathrm{OH})_{4}\left(\mathrm{p} K_{\mathrm{a} 1}\right)$ is 9$10^{16,17,38-45}$ and the subsequent $\mathrm{p} K_{\mathrm{a}}$ values are estimated as 11.7-
13.4. ${ }^{17,38-45}$ While discussing quantitative values concerning silicic acid, we must remember that $\mathrm{Si}(\mathrm{OH})_{4}$ is highly unstable and exists at low $\mathrm{pH}$ or in very diluted solutions only. In other cases, various condensed forms appear in several seconds which poses a challenge to the investigators. So, we have some intervals in the measured values. Condensation of silicic acid is a reversible process and the minimal concentration of monomeric $\mathrm{Si}(\mathrm{OH})_{4}$ in equilibrium with solid silica or condensed soluble siliceous particles is estimated as $2-3 \mathrm{mM}^{\mathbf{1 9}}$

Assuming $\mathrm{p} K_{\mathrm{a} 1}$ as 10 , one can calculate the dependence of the concentration of unionized $\mathrm{Si}(\mathrm{OH})_{4}$ species on $\mathrm{pH}$ (Fig. $2 \mathrm{~A}$ ). The $\sim \mathrm{Si}-\mathrm{OH}$ moieties occur at relatively high $\mathrm{pH}$ and according to our observations, $100 \mathrm{mM}$ aqueous solutions of sodium silicate contain $>50 \%$ of oligosilicates after several weeks of storage. A decrease in $\mathrm{pH}$ to 9.5-10.5 results in formation of considerable amounts of $\mathrm{Si}(\mathrm{OH})_{4}$ and $\mathrm{Si}(\mathrm{OH})_{3} \mathrm{O}^{-}$molecules which leads to fast condensation of the silicic acid monomers. Further decrease of $\mathrm{pH}$ to 7 and below results in almost completely unionized silicic acid and the condensation rate drops.

The other participant of the condensation reaction is oligosilicate molecules or poly(silicic acid) (PSA): dimers, trimers and larger particles. PSA contains more acidic groups than monomeric $\mathrm{Si}(\mathrm{OH})_{4}$. The $\mathrm{p} K_{0}$ for ionization of a first $\sim \mathrm{Si}-\mathrm{OH}$ group on the surface of PSA particles is estimated as $6.8 .^{\mathbf{1 9 , 4 6}}$ Thus, after formation of PSA particles we have $\sim \mathrm{Si}-\mathrm{O}^{-}$moieties even at neutral and acidic conditions (Fig. 2B). This results in two peculiarities of silicic acid condensation:

(a) Condensation at $\mathrm{pH} 7$ and below proceeds with an incubation period which is necessary for formation of primary PSA particles. ${ }^{19,47}$
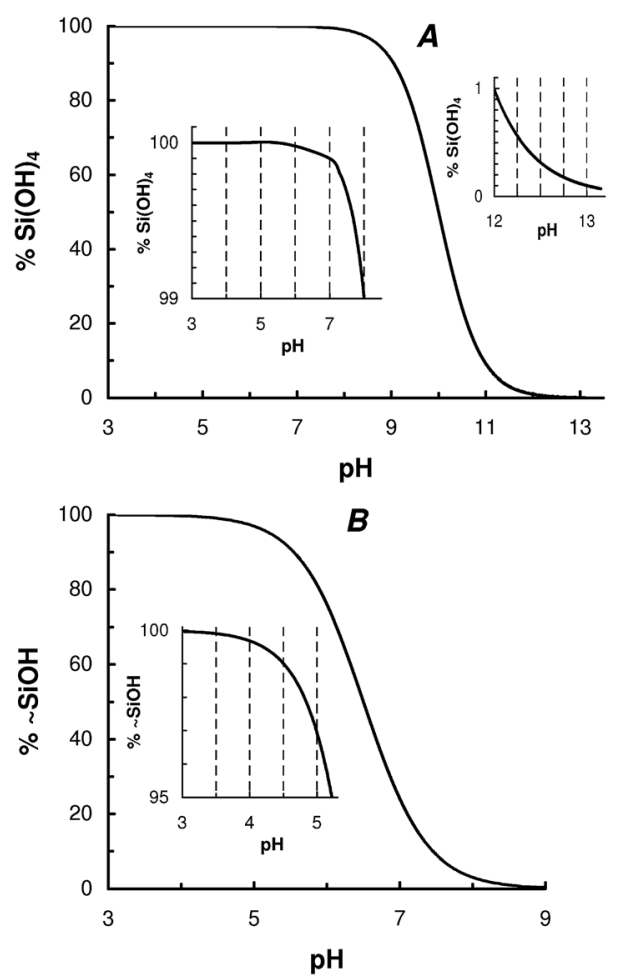

Fig. 2 Effect of $\mathrm{pH}$ on the percentages of $\mathrm{Si}(\mathrm{OH})_{4}$ and $-\mathrm{SiOH}$ moieties. 
(b) The condensation rate depends not only on $\mathrm{pH}$ but also on prehistory of the solution, e.g. if monomeric silicic acid is maintained at $\mathrm{pH} 5$, it will be stable for some time, but if the solution is stored at $\mathrm{pH} 9$ for several minutes prior to incubation at pH 5, PSA particles will appear and we will observe condensation on the surface of these particles. This unique characteristic opens up a wide range of possibilities for design of siliceous materials. However, it also poses difficulties in data reproducibility.

Thus, the first stage of silicic acid condensation results in formation of soluble PSA particles accompanied by a decrease of $\mathrm{Si}(\mathrm{OH})_{4}$ concentration to $2-3 \mathrm{mM}$. Further fate of these particles depends mainly on $\mathrm{pH}$ and total silicon concentration. There are two possibilities for transformation of the primary PSA particles: aggregation and Ostwald ripening. ${ }^{19,27}$ Aggregation is observed at $\mathrm{pH}<7$ because primary particles are almost uncharged in this condition and therefore can interact with each other giving rise to $3 \mathrm{D}$ gel structures at concentration greater than $50-100 \mathrm{mM}^{48}$ Ostwald ripening ${ }^{49,50}$ is a process of growing large particles at the expense of small particles and this is more characteristic at $\mathrm{pH}>7$ where PSA particles bear negative charge that prevents aggregation through electrostatic repulsion.

Study of the silicic acid condensation in aqueous medium requires methods for precisely measuring the concentration of monomeric silicic acid. The widely used procedure for quantification of silicic acid involves the reaction of silicic acid with molybdate in acidic medium resulting in the formation of yellow molybdosilicate complexes, the absorbance of which can be measured using a spectrophotometer. ${ }^{51-53}$ Sensitivity of the method increases when the yellow complex is reduced to blue products with $N$-methylaminophenol (metol). ${ }^{54,55}$ The procedure is optimized to allow only monomers and dimers of silicic acid to react with the molybdate reagent. ${ }^{24,31,56}$ The molybdate method is not applicable in the presence of phosphates, e.g. when a phosphate buffer is used. An alternate method to measure monomeric silicic acid and its various condensed forms is through ${ }^{29} \mathrm{Si}$ NMR spectrometry. ${ }^{48}$ Unfortunately, the natural content of this isotope $(4.7 \%)$ does not permit the study of fast reactions at relatively low concentrations (tens of mmol). Attenuated total reflection Fourier transform infrared (ATRFTIR) spectroscopy is also must be mentioned as a convenient and quick method which allows to distinguish monomer and oligomer siliceous species using absorbance in the wavenumber region $1250-850 \mathrm{~cm}^{-1} .^{57}$

\section{Influence of organic polymers on condensation of monomeric silicic acid}

A scan of literature reveals many reports that have described silicic acid condensation in the presence of organic polymers. These have been summarized in Table 1 . Study of $\mathrm{Si}(\mathrm{OH})_{4}$ condensation using the molybdate method demonstrated the influence of some polymers on kinetics of the reaction. Acceleration ${ }^{58,59,63,64,73,82,96,99,108,112,136,158,159}$ and inhibi$\operatorname{tion}^{24,72,83-85,102,124,133-135,137}$ of the reaction monitored as consumption of $\mathrm{Si}(\mathrm{OH})_{4}$ has been reported. As mentioned earlier, the condensation of monomeric silicic acid near neutral $\mathrm{pH}$ values proceeds mainly through its reaction with PSA particles. Polymers can influence the process by interaction with $\mathrm{Si}(\mathrm{OH})_{4}$ or with PSA molecules. The interaction between PSA and functional organic polymers proceeds similar to the interpolymer reactions between two organic polymers. These reactions have several peculiarities. ${ }^{168}$

(a) The interaction is caused by relatively weak bonds which cannot result in new compounds in the case of monomeric analogs. For example, a weak poly(acrylic acid) can interact with a very weak base poly(1-vinylpyrrolidone) in water solution giving rise to insoluble compound of $1: 1$ stoichiometry: $^{169}$

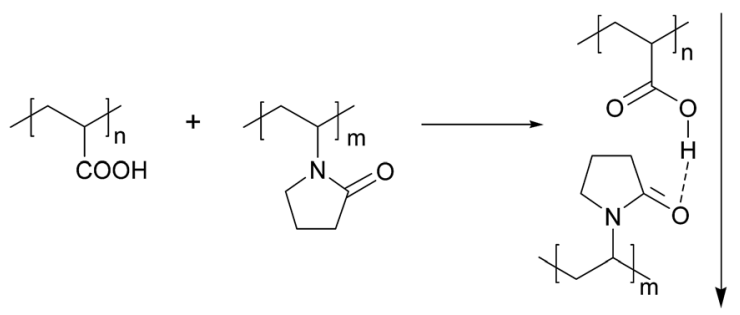

(b) The interpolymeric reactions are favorable from an entropy point of view comparing with a reaction between small molecules and unusual reactions are possible with polymers, e.g. displacement of strong acid with weak acid:

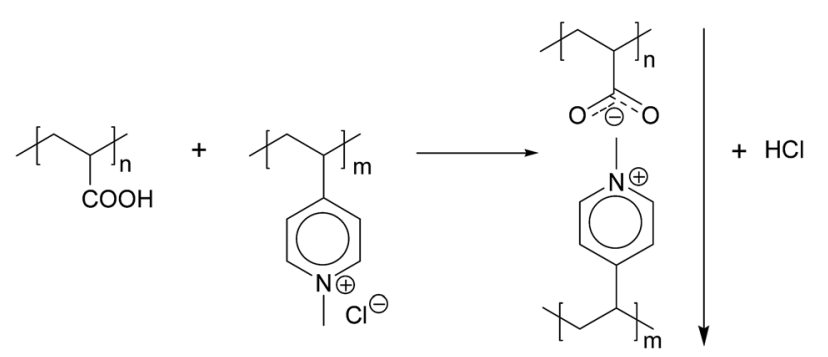

(c) The cooperative character of the interpolymeric reactions appears in the presence of a minimal critical length of the interacting sequences after which the interaction becomes almost irreversible. The value of critical length depends on the nature of the interacting groups and possible supramolecular effects. For instance, substitution of poly(acrylic acid) with poly(methacrylic acid) in the reaction with polyethylene glycol (PEG) decreases the critical length from $\approx 100$ to $\approx 20$ because of the stabilizing effect arising due to the hydrophobic interactions of the methyl groups from the methacrylic acid moiety. ${ }^{170}$

(d) The stoichiometry of the interacting polymeric chains is also important, especially in the case of rigid chain polymers and PSA particles which are strengthened due to cross-linking through $\mathrm{Si}-\mathrm{O}-\mathrm{Si}$ bonds.

Thus, organic polymers which bear basic groups can interact with PSA by two ways:

1. Ionic bonds in the case of relatively strong polymeric bases or polymeric cations: 
Table 1 Influence of water soluble polymers on silicic acid condensation

\# $\quad$ Polymer $\quad$ Precursor $\quad$ Brief description of the result Ref.

polyamines:

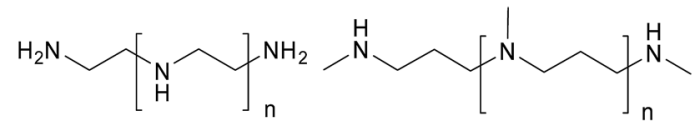<smiles>[R]N([R])CCC(C)(C)N(C)CCC(C)(C)N([R])[R]</smiles>

$\mathrm{n}=5-20, \mathrm{R}=\mathrm{H}, \mathrm{CH} 3$

Triethylenetetramine, pentaethylenehexamine:

2<smiles>CC(N)CNCCN</smiles>

$$
n=2-4
$$

Long-chain polyamines from diatoms

3<smiles>[R]N([R])CCCC(C)N(C)CCC(C)(C)N([R])[R]</smiles>

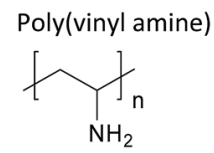<smiles>[CH2-]NCC(CC(C)C)C(C)(C)CC(C)C</smiles>

TMOS

$\mathrm{Na}_{2} \mathrm{SiO}_{3}$

$\mathrm{K}_{2}$-SiKat

$\mathrm{Na}_{2} \mathrm{SiO}_{3}$

TMOS
Polyamines accelerate silicic acid condensation. Siliceous precipitate consist of $200-400 \mathrm{~nm}$ in diameter spheres, propylene based polyamines give hollow spheres

Spherical particles of $200-300 \mathrm{~nm}$ size were obtained at $\mathrm{pH} 7$ (phosphate buffer). Addition of the enzymes (proteases) to the systems resulted in their encapsulation

Spherical composite particles were obtained. Particle size increased up to $900 \mathrm{~nm}$ when phosphate buffer was applied

Polymer accelerates condensation at $\mathrm{pH}$ 5.5-10 giving rise to soluble composite nanoparticles or composite precipitates depending on polymer : Si ratio. Long chain polymeric fraction 63 and 64 (polymerization degree 11000 ) gives core-shell particles consisting of one macromolecule and several 3-6 $\mathrm{nm}$ silica particles in the core Composite nanoparticles were found in the solution during condensation. Changing of citrate buffer with phosphate results in increase of diameter of soluble particles (from 5 to $120 \mathrm{~nm}$ ) and size of spherical particles in precipitate (from 170 to more than $2500 \mathrm{~nm}$ ). Condensation at pH $6 \quad 65-70$ resulted in smoother surface of the particles than at $\mathrm{pH} 7$. Amorphous silica fiber-like structures $100 \mathrm{~nm}$ in diameter were obtained under externally applied shear (stirring the reaction mixture and (b) flowing Through a $1 / 8$ in. Tube) Addition of cationic surfactant $N-71$ cetyl- $N, N, N$-trimethyl ammonium bromide decrease size of the obtained insoluble particles from 3000 to $45-80 \mathrm{~nm}$ The polymer did not influence $\quad 72$ considerably on the rate of $\mathrm{Si}(\mathrm{OH})_{4}$ condensation at $\mathrm{pH}$ 5.5-6 but can interact with silica nanoparticles, especially in the presence of phosphate buffer 
Table 1 (Contd.)

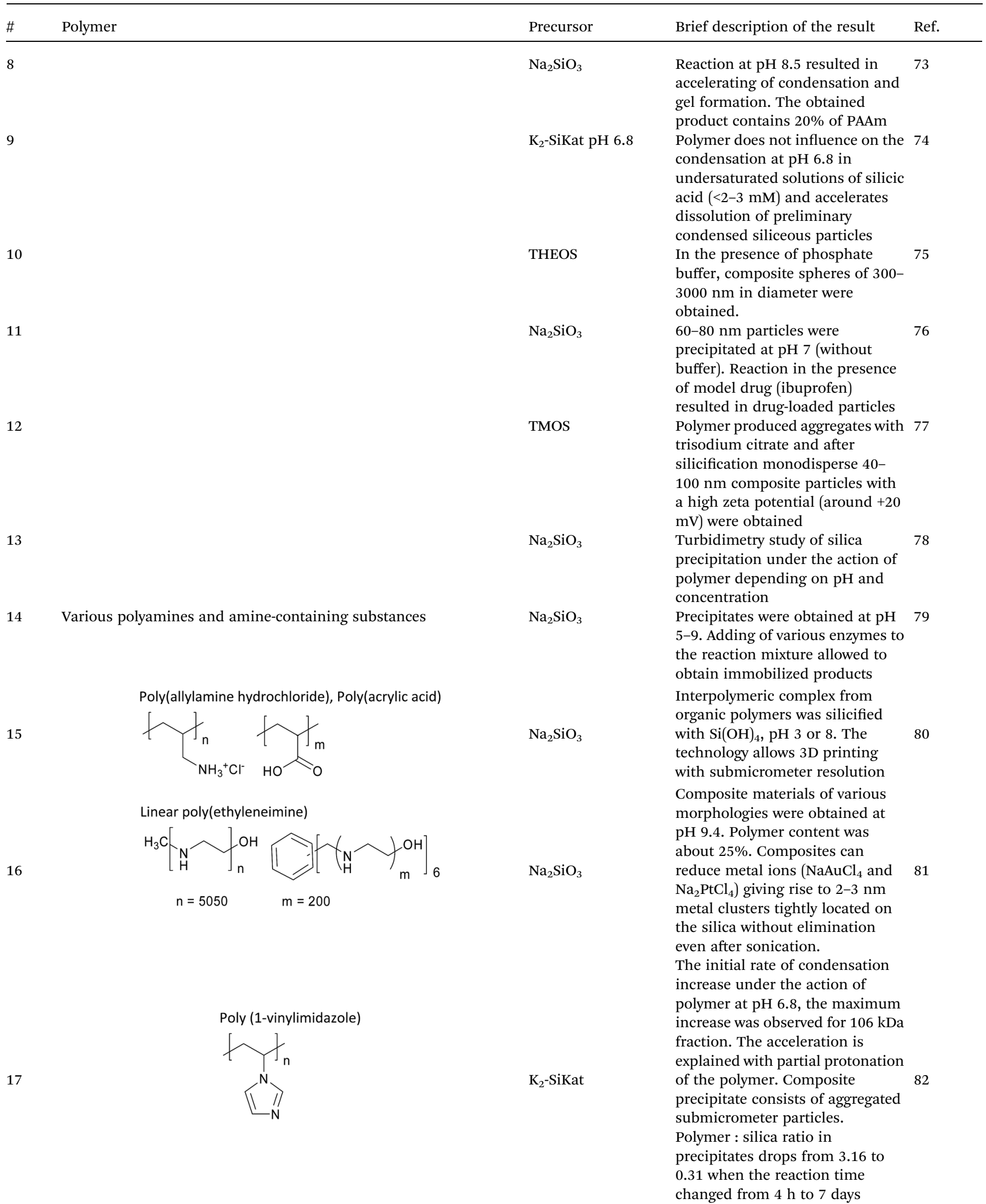


Table 1 (Contd.)

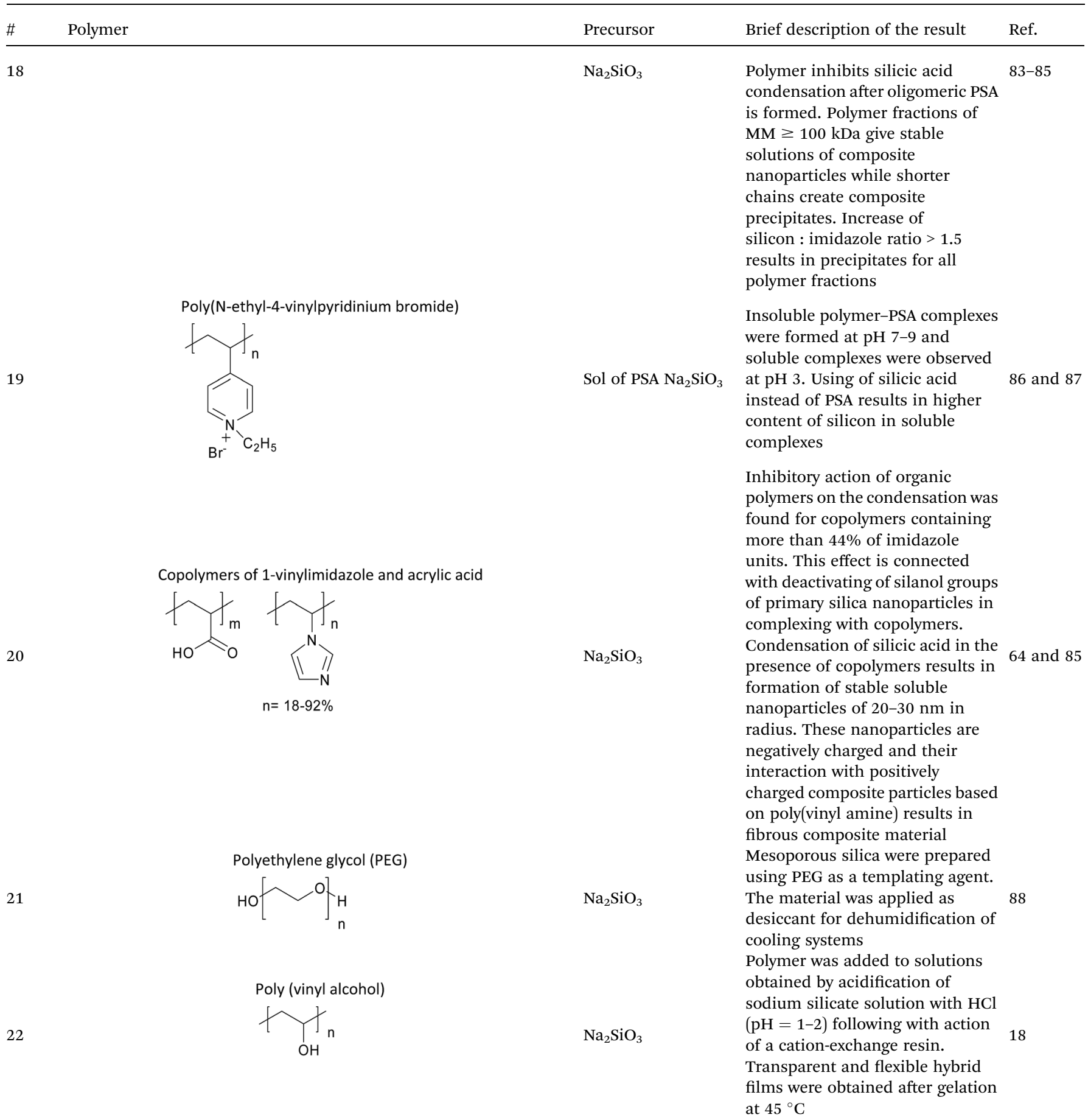


Table 1 (Contd.)

\# $\quad$ Polymer

Span-80 and Tween-80<smiles>CCCCCCCC/C=C\CCCCCCCC(=O)OCC(O)C1OC2COC1[C@H]2O</smiles>

23

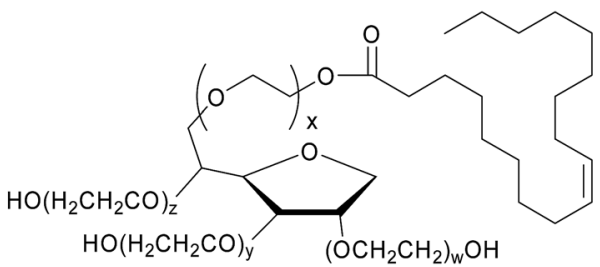

$w+x+y+z=20$

Poly(2-(dimethylamino) ethyl methacrylate)

24<smiles>CCC(C)(C)C(=O)OCCN(C)C</smiles>

Poly(2-(dimethylamino)ethyl methacrylate)

25<smiles>CCC(C)(C)C(=O)OCCN(C)C</smiles>

Poly(acrylamide-co-2-(dimethylamino) ethyl methacrylate, methyl chloride quaternized)

26

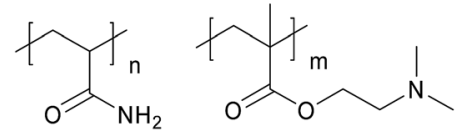

PEG-block-polycation copolymer

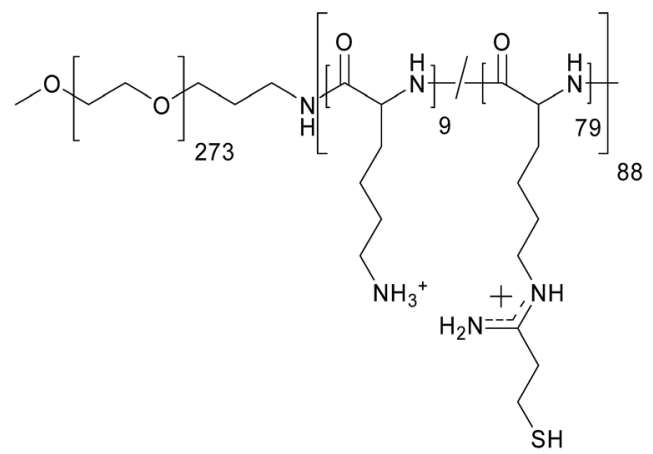

Poly (acrylic acid) with grafted polyamine chains<smiles>CC(C)(C)CC(C(=O)O)C(C)(C)C</smiles><smiles>CCC(C)C(=O)N(C)CCCN(C)CC(C)CCNC</smiles>

$m=2.2 \%$

Precursor

Brief description of the result Ref.

Water glass

Sol PSA

$\mathrm{Na}_{2} \mathrm{SiO}_{3}$

TMOS

$\mathrm{Na}_{2} \mathrm{SiO}_{3}$

$\mathrm{Na}_{2} \mathrm{SiO}_{3}$
Mesoporous silica microspheres for delivering poorly water-soluble drugs were prepared by silicic acid condensation in oil emulsion
Insoluble polymer-PSA complexes were formed at $\mathrm{pH}$ 7-9 and soluble complexes $\left(R_{\mathrm{g}}=24 \mathrm{~nm}\right)$ were observed at $\mathrm{pH} 3$. The solubility was observed up to $50 \%$ of polymeric units interacted with PSA by ionic bonds

Particles of $30-800 \mathrm{~nm}$ in diameter were obtained when pH 93 changed from 6.6 to 8.1

Composite porous particles of $50 \mathrm{~nm}$ diameter with positive $\zeta$ potential at $\mathrm{pH} 7$ were obtained
Polymer polyplex with siRNA was obtained and silicified pH 7.4 (HEPES buffer). The obtained 100-140 nm particles were used for siRNA delivery

The polymer accelerate condensation at $\mathrm{pH} 5.5$ gives rise to soluble composite nanoparticles (170-190 $\mathrm{nm}$ in diameter). According to TEM data, polymer and silica are uniformly 96 distributed in these particles.

Sedimentation-induced concentration $(50000 g)$ results in precipitate with reduced amount of polymer $(<4 \%)$ 
Table 1 (Contd.)

\begin{tabular}{|c|c|c|c|c|}
\hline \# & Polymer & Precursor & Brief description of the result & Ref. \\
\hline 29 & Polystyrene latexes modified with $\sim \mathrm{NH}_{2}$ and $\sim \mathrm{COO}^{-}$groups & $\mathrm{Na}_{2} \mathrm{SiO}_{3}$ & $\begin{array}{l}100-200 \mathrm{~nm} \text { core-shell particles } \\
\text { were obtained at } \mathrm{pH} 9.7 \text {. Hollow } \\
\text { particles were obtained with } \\
\text { calcination. Slow drying of the } \\
\text { particles on a surface resulted in } \\
\text { highly organized hexagonal } \\
\text { lattices. }\end{array}$ & 97 \\
\hline
\end{tabular}

Quaternized 2-(dimethylamino)ethylmethacrylate (DMAEMA) homopolymer and block copolymers of DMAEMA with methyl methacrylate (MMA)<smiles>CC(C)(C)C(C)(C)C(=O)OCC[N+](C)(C)C</smiles><smiles>COC(=O)C(CC(C)(C)C)(C(C)(C)C)C(C)(C)CC(C)(C)C(C(=O)OCC[N+](C)(C)C)(C(C)(C)C)C(C)(C)C</smiles><smiles>CC(C)(C)CC(C)(C)C(=O)OCC[N+](C)(C)C</smiles><smiles>CCC(C)(C)C(C)(C)CC</smiles>

Branched polyethyleneimine Fmoc-diphenylalanine peptide<smiles>CCNCCN(CCNCCN)CCN(CCNCCN)CCNCCN(CC)CCN</smiles><smiles>O=C(N[C@@H](Cc1ccccc1)C(=O)N[C@@H](Cc1ccccc1)C(=O)O)OCC1c2ccccc2-c2ccccc21</smiles>

Polymer of 2-(methacryloyloxy)ethyltrimethylammonium chloride on polystyrene particles employed as a template
$\mathrm{Na}_{2} \mathrm{SiO}_{3}$

$\mathrm{Na}_{2} \mathrm{SiO}_{3}$

$\mathrm{Na}_{2} \mathrm{SiO}_{3}$
The polymers accelerate condensation at $\mathrm{pH} 7.2$ giving precipitates from aggregated $\approx 100 \mathrm{~nm}$ particles. ${ }^{29} \mathrm{Si}$ MAS NMR 99 spectra show increase in condensation degree with increase of quaternization degree

Self-organization of the organic components followed by silicification resulted in $800 \mu \mathrm{m} \quad 100$ beads which can encapsulate enzyme (epoxide hydrolase $\mathrm{SpEH}$ )

Hollow siliceous particles (1-2 $\mu \mathrm{m})$ were prepared starting from polystyrene beads. These particles were used in UV blocking 101 applications, such as cosmetics and finishing materials for buildings 
Table 1 (Contd.)

\# $\quad$ Polymer

.

34

35

36

37
Precursor

$\mathrm{Na}_{2} \mathrm{SiO}_{3}$

poly-N-methacryloyl- L-histidine (poly-MHist) and poly(N-acryloyl-L-phenylalanine) (poly-PHE)<smiles>CC(C)(C)C(C)(C)C(=O)NC(Cc1c[nH]cn1)C(=O)O</smiles><smiles>CCC(C)(C)C(=O)NC(Cc1ccccc1)C(=O)O</smiles>

$\mathrm{Na}_{2} \mathrm{SiO}_{3}$

Epicholorhydrin-dimethylamine copolymer and poly(diallyldimethylammonium chloride)<smiles>CC(C)(C)CC(O)CC(C)(C)CC1C[N+](C)(C)CC1CC(C)(C)C</smiles>

Poly(diallyldimethylammonium chloride) sodium polystyrene sulfonate<smiles>CCC1C[N+](C)(C)CC1CC(C)(C)C</smiles><smiles>CC(C)(C)C(c1ccc(S(=O)(=O)O)cc1)C(C)(C)C</smiles>

Poly(diallyldimethylammonium chloride) and sodium alginate<smiles>CC(C)(C)CC1C[N+](C)(C)CC1CC(C)(C)C</smiles>

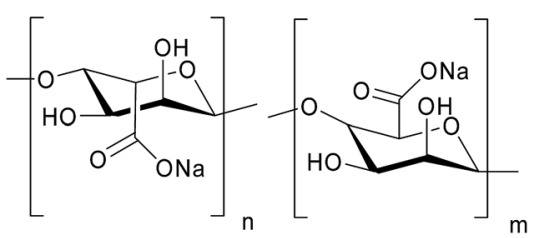

Poly-L-lysine<smiles>CC(C)N[C@@H](C)C(=O)NC(C)N</smiles>

TMOS
TMOS

$\mathrm{Na}_{2} \mathrm{SiO}_{3}$
Brief description of the result

Ref.

Poly-MHist inhibits initial condensation and it is most efficient at $\mathrm{pH} 7$ (where the polymeric chains are neutral) than at pH 5.5 and 8.5. The inhibition effect was not observed after $8 \mathrm{~h}$. 102 The polymer is not found in solid products. Poly-PHE does not influence of the silicic acid condensation

Treatment of soil (sand) particles with polymeric cation following with silicification improved the engineering properties of soils

Yeast cells were treated with polymeric cation and anion followed by encapsulation with silicic acid. The cell viability after 30 days increased $>2$ times comparing with native cells

Dunaliella tertiolecta cells were encapsulated into hybrid organoinorganic beads. Photosynthetic activity remained for at least 400 105 days

200-400 nm particles were obtained at $\mathrm{pH} 7$ in the presence of phosphate buffer. Poly(allyl amine) addition results in formation of disk-like 100-200 nm structures

Precipitation was observed at $\mathrm{pH} \quad 107$ 6.8, 7.5 and 9.2 Tris buffer solutions. Addition of alcohol or carbohydrates resulted in decrease of diameter of spherical products from 540 to $80 \mathrm{~nm}$ 200-1100 $\mathrm{nm}$ bimodal distributed 66 particles were obtained at $\mathrm{pH} 6$ and 7 in the presence of phosphate buffer. Particle surface was smoother at pH 6 than at $\mathrm{pH} 7$ 
Table 1 (Contd.)

\#

\# Polymer

Precursor

Brief description of the result

Ref.

41

42

43

$\mathrm{K}_{2}$-SiKat

44
THEOS

$\mathrm{Na}_{2} \mathrm{SiO}_{3}$

Poly-I-lysine and poly-I-arginine<smiles>CC(=O)[C@H](C)NC(C)CN</smiles><smiles>C[C@H](NC(C)(C)C)C(=O)C(C)(C)C</smiles>

Poly(lysine), poly(allylamine)

49<smiles>[CH][C@H](NC(C)(C)CN)C(=O)C(C)(C)C(C[NH3+])CC(C)(C)C</smiles>

Waterglass
TMOS, waterglass

The polymer accelerated

108

condensation in phosphate buffer

at $\mathrm{pH} 7.5$ and 11.2. Polymer

containing 222 amino acid

residues gives hexagonal silica

platelet $(0.5$ and $5 \mu \mathrm{m})$ and

polymer of 20 units gives spherical

$200 \mathrm{~nm}$ particles

Hexagonal structures (500-1000

$\mathrm{nm}$ ) were observed with non-

perturbed solutions and passing

the solution throw a tube results

in petal-like and fiber-like

structures

Initial condensation rate at pH $6.8 \quad 24$

(non-buffered solutions)

increased with increase of the

oligomer length (2-5 units) and

does not change in the case of

polymer. Oligomers give 85-

$140 \mathrm{~nm}$ composite particles and

polymer - $460 \mathrm{~nm}$

Polymer does not influence the

condensation at $\mathrm{pH} 6.8$ in

undersaturated solutions of silicic

acid $(<2-3 \mathrm{mM})$ and accelerates

dissolution of preliminary

condensed siliceous particles.

Spherical (200-400 $\mathrm{nm}$ ) and

hexagonal (400-1000 nm)

composite particles were obtained

at pH 6.8 (phosphate buffer)

Silica was obtained by

condensation at pH 5 in pore

channels of polycarbonate

membranes using

preimmobilized poly-L-lysine

Condensation at pH 7 (phosphate 111

buffer) resulted in hexagonal

composite particles (500-2000

$\mathrm{nm}$ ) due to polymer self-

organization. Spherical particles

were also observed with poly-D-

lysine

Poly-L-lysine accelerated

condensation at $\mathrm{pH} 7.2$ (Tris- $\mathrm{HCl}$

buffer), increase in the polymer

chain length increased the

acceleration. Both polymers give

composite precipitates containing 50-100 nm particles at $\mathrm{pH} 7.2$ and 9.2, while precipitation was not observed at $\mathrm{pH} 4.9$

Particles with non-uniform

surface were obtained at pH 3.5

(citrate buffer) 
Table 1 (Contd.)

\# Polymer

Precursor

Brief description of the result

Ref.

Glycine oligomers

50<smiles>CC(=O)C(C)C(C)NCC1CC1</smiles>

Poly-L-arginine

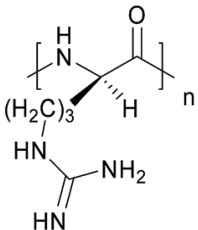<smiles>CC(C)NC(C)C(=O)NC(C)C(=O)O</smiles>

poly(D-glutamic acid)<smiles>CC(C)C(=O)[C@H]1NC2CCC(C2)C1C(=O)O</smiles>

54

Poly-L-histidine<smiles>CC(C)(C)NC(Cc1c[nH]cn1)C(=O)C(C)(C)C</smiles>

Homopeptides of serine, lysine, proline and aspartic acid<smiles>CC(C)(C)NC(CO)C(=O)C(C)(C)C</smiles><smiles>CC(N)C(=O)C(C)N</smiles><smiles>CC(=O)N1CCCC1C(C)(C)C</smiles>

56<smiles>CC(C)(C)CCCCCCNC(=O)C(CC(=O)O)C(C)(C)C</smiles>

$\mathrm{K}_{2}$-SiKat

TMOS, waterglass

$\mathrm{Na}_{2} \mathrm{SiO}_{3}$

$\mathrm{Na}_{2} \mathrm{SiO}_{3}$

TMOS

$\mathrm{K}_{2}$-SiKat

Waterglass
Initial condensation rate was slightly decreased at $\mathrm{pH} 6.8$ (without buffer)

The polymer precipitates silica at pH 7 (phosphate and phosphatecitrate buffers) in the form of 300500 or $<100 \mathrm{~nm}$ spheres in the case of polymers with MW $13 \mathrm{kDa}$ and $55.3 \mathrm{kDa}$ respectively

Polyarginine formed polyplexes 115 with plasmid DNA and silicic acid was added at pH 7.3 (HEPES buffer) giving rise to Si-coated nanoparticles (114-126 $\mathrm{nm}$ in diameter). These particles were used for transfection Multilayered particles were prepared starting from polymers, histone mimetic H3K4(Me3) tail peptide and GFP plasmid DNA or GFP mRNA. This complex was used for silicic acid condensation 116 (pH 7.4, Tris buffer) and poly-Larginine was placed on the siliceous surface. The resulted $170 \mathrm{~nm}$ particles were used for transfection

Precipitate of aggregated 50 and 150-200 nm spheres was obtained 117 at pH 7 (phosphate buffer)

The polymer accelerates silicic

acid condensation at $\mathrm{pH} 6.8$ (without buffer). Composite netlike precipitates contain polymer Peptides exhibit a stronger catalytic effect on silicic acid condensation than amino acids. Poly-lysine and poly-proline lead to the precipitation of solid phases containing both silica and peptides. The precipitates are formed of agglomerated quasispherical particles (diameter $<100$ $\mathrm{nm})$. Gels prepared in the presence of p-Pro exhibit a rather flat surface, whereas those precipitated in the presence of $\mathrm{p}$ Lys exhibit a more uneven surface 
Table 1 (Contd.)

\# Polymer

Precursor

Brief description of the result

Ref.

Poly(ethylene glycol)-b-poly(L-lysine)-b-poly(styrene) (PEG-PLL-PS) triblock copolymer

57

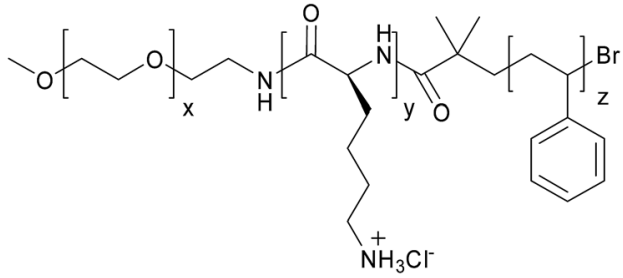

58

$\beta$-Casein

Chitosan

59

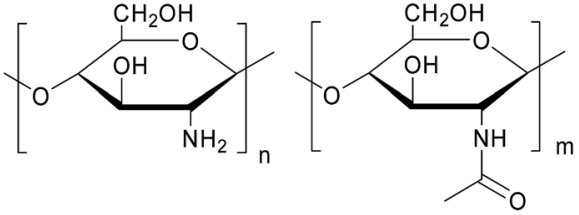

60

61

Phosphorylated chitosan

62

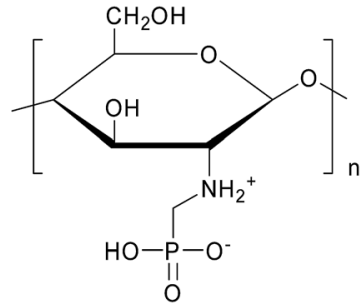

$\mathrm{Na}_{2} \mathrm{SiO}_{3}$

Condensation at $\mathrm{pH} 7.5$

(phosphate buffer) resulted in Janus hollow silica spheres with hydrophobic PS chains tethered to the inner surface and PEG attached to the outer surface

$\mathrm{Na}_{2} \mathrm{SiO}_{3}$

TMOS

$17 \mathrm{~nm}$ particles of protein coated 120 with silica were obtained at pH 5.9 (citrate buffer)

Spherical composites $(1000 \mathrm{~nm}$ aggregates from 15 and 50-

$200 \mathrm{~nm}$ particles) were obtained at 121 pH 5.8 in the presence of phosphate ions

$\mathrm{Na}_{2} \mathrm{SiO}_{3}$

Manganese peroxidase was

immobilized into $100 \mathrm{~nm}$

composite particles which protected it from ultrasonic destruction

Thermally stable microcapsules as 123 food additives were prepared from soybean oil (core) and composite shell from chitosan and precondensed silicic acid

Inhibition of the condensation was observed at pH 7 and 8.33. Composite particles of various sizes were obtained: $100 \mathrm{~nm}(6 \mathrm{~h}), 124$ $300-500 \mathrm{~nm}(72 \mathrm{~h})$, aggregates $>2000 \mathrm{~nm}$ (4 weeks) 
Table 1 (Contd.)

\# $\quad$ Polymer $\quad$ Precursor $\quad$ Brief description of the result

Xanthan (1), locust bean gum (2) and Cationic derivative of hydrohyethylcellulose (cat-HEC) (3):

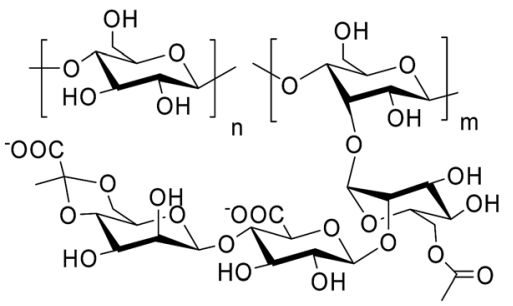

(1)

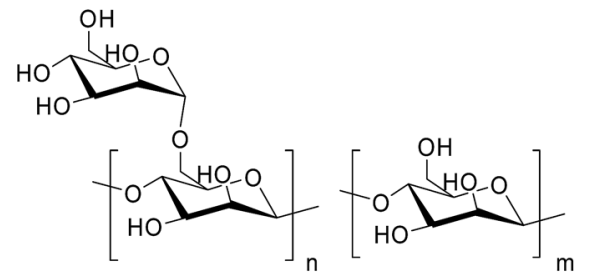

63

(2)

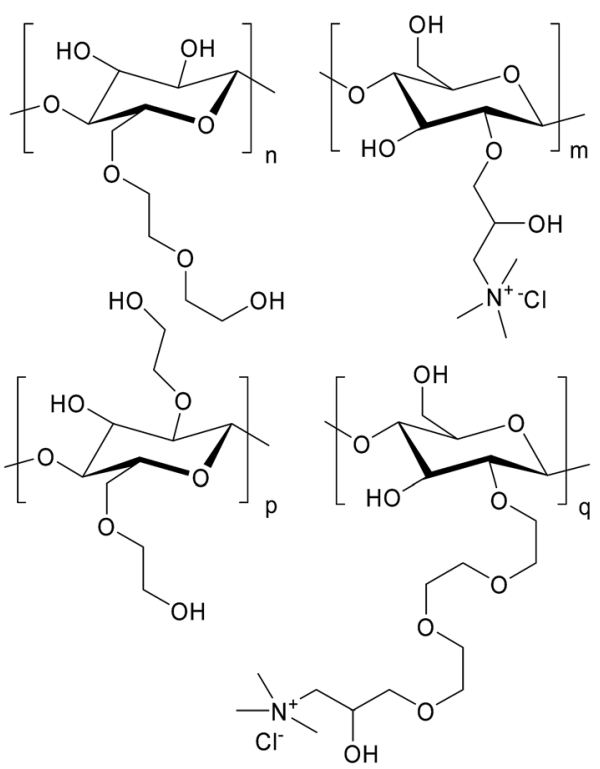

(3) composite gel was obtained and 125 and used to immobilize enzymes 
Table 1 (Contd.)

\# $\quad$ Polymer

Chitosan, hyaluronate and $\alpha$-cyclodextrin :

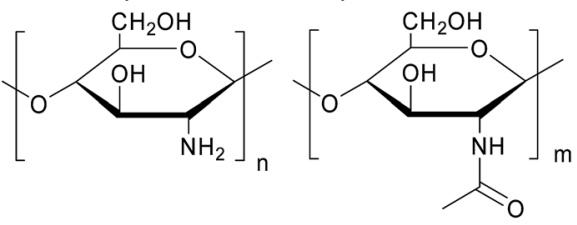

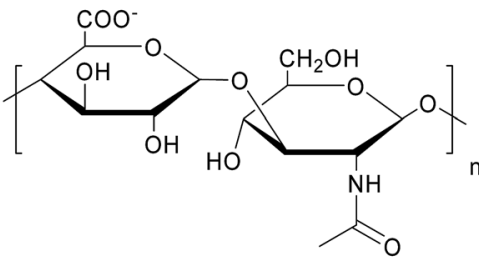

64<smiles></smiles>

Hydrogels were obtained at $\mathrm{pH}$

THEOS
5.5-6

127 
Table 1 (Contd.)

\# Polymer

Precursor

Brief description of the result

Ref.

Chitosan (1), cationic derivatives of hydroxyethylcellulose (2), hydroxyethylcellulose (3), Laminaran (4), Arabinogalactan (5) and other polysaccharides

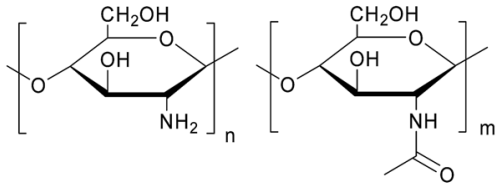

(1)

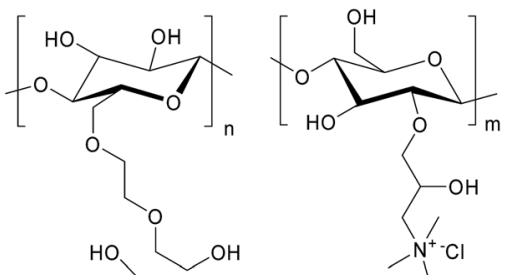

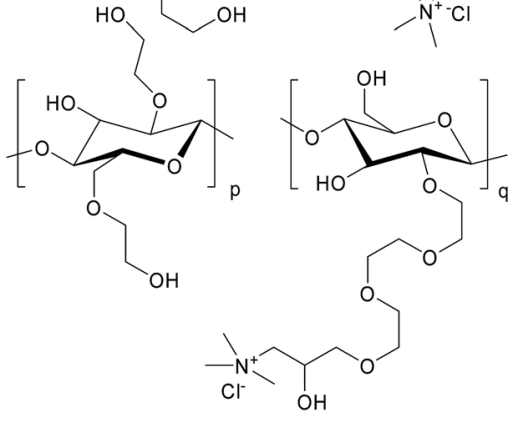

(2)

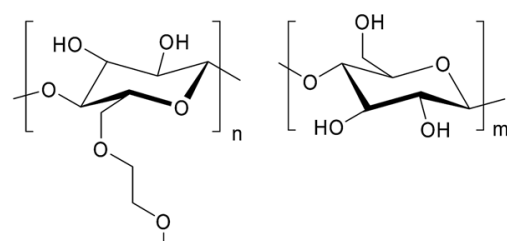<smiles>COC(OCCO)C(OCCO)C(OCCO)C(C)(C)OC(C)(C)C</smiles><smiles>CCOC1(C(O)C(OCCOCCO)OC(C)(C)C)CCOCCOC1</smiles>

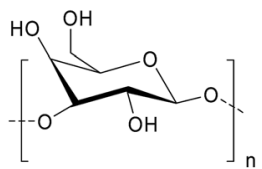

(4)<smiles>CC(C)(C)OC1OC(C)(C)C(O)C(O)C1O</smiles>

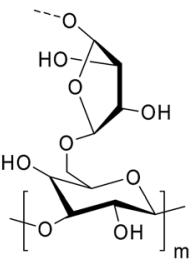

(5)
Formation of composite gels is described

128 and 129 
Table 1 (Contd.)

\# $\quad$ Polymer

66

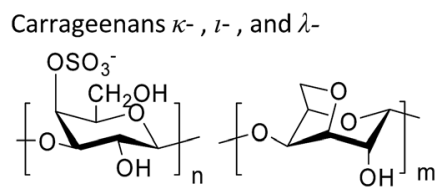<smiles>O</smiles>

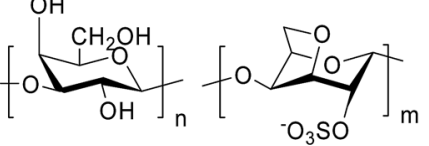

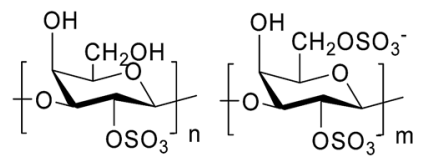

Maleic acid - 1-vinylpyrrolidone copolymer modified with diamines

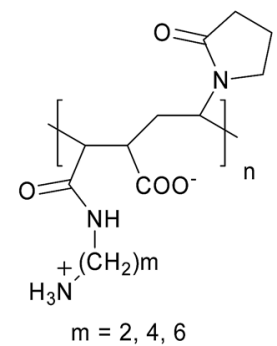

Polyethyleneimine, polyethylene glycol, chitosan, phosphonomethylated chitosan
Precursor

Brief description of the result

Ref.

Polymers promoted the

mineralization, acting as

a template for the inorganic

component. The increase of

silicate concentration led to a rise in the stiffness and brittleness of the material, whereas the polysaccharide addition made it softer and more elastic. $k$ Carrageenans brought about shrinkage of hybrid materials that 130 led to water separation, while $\iota$ and $\lambda$-carrageenans did not induce the syneresis. $\kappa$ - and $\iota$ carrageenans experienced a thermoreversible phase transition in the hybrid materials owing to the helix-coil transition

The copolymers slightly decrease condensation rate at $\mathrm{pH}$ 5.5-6 (acetate buffer) and interact with 72 primary PSA particles giving rise to composites

$\mathrm{Na}_{2} \mathrm{SiO}_{3}$ Stabilization of soluble silicic acid 131 with these polymers is discussed 
Table 1 (Contd.)

\#

Polymer

Precursor

Brief description of the result

Ref.

Polyethyleneimine (1), poly(allylamine hydrochloride) (2), poly(acrylamide-co-diallyldimethylammonium chloride) (3).<smiles>CCC[NH+](CCC)CC[NH+](CCC)CCC</smiles>

(2)

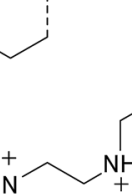

$\mathrm{H}_{2}$

69

$\begin{array}{lll}\text { Cationic inulin and poly(acrylamide-co- } & \text { and } \\ \text { diallyldimethylammonium chloride) } & \end{array}$

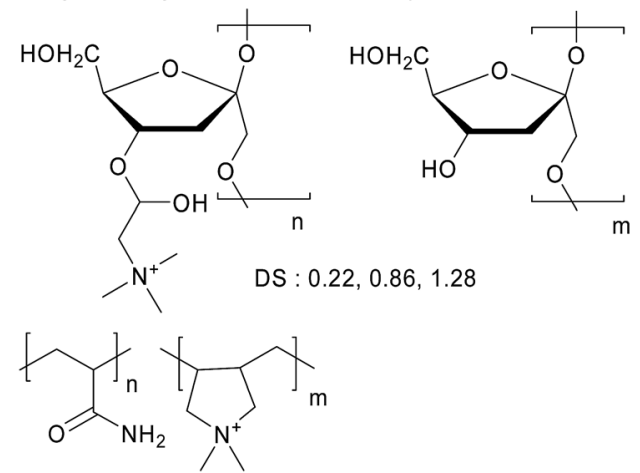

Cationic polymers enhance silicate solubility

132
(1)<smiles>CCC(CC)C(C)(C)C1C[N+](C)(C)CC1CC(C)(C)C</smiles>

(3)

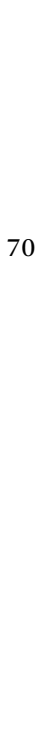

$\mathrm{Na}_{2} \mathrm{SiO}_{3}$
Polymers inhibit silicic acid

$\mathrm{Na}_{2} \mathrm{SiO}_{3}$ condensation at $\mathrm{pH} 7$ and cationic charge density correlates with 133 inhibitory activity 
Table 1 (Contd.)

\# Polymer

Precursor

Brief description of the result

Ref.

Polyethyleneimine (1); phosphonomethylated polyethyleneimine (2); polyallylamine (3); poly(acrylamide-codiallyl-dimethylammonium chloride)

(4); phosphonomethylated Chitosan (5); polyethylene glycol; phosphonium-grafted polyethylene glycol (6); polyvinylpyrrolidone (7); poly(1-vinylpyrrolidone-co-2dimethylaminoethyl methacrylate) (8); polyvinyl alcohol (9)

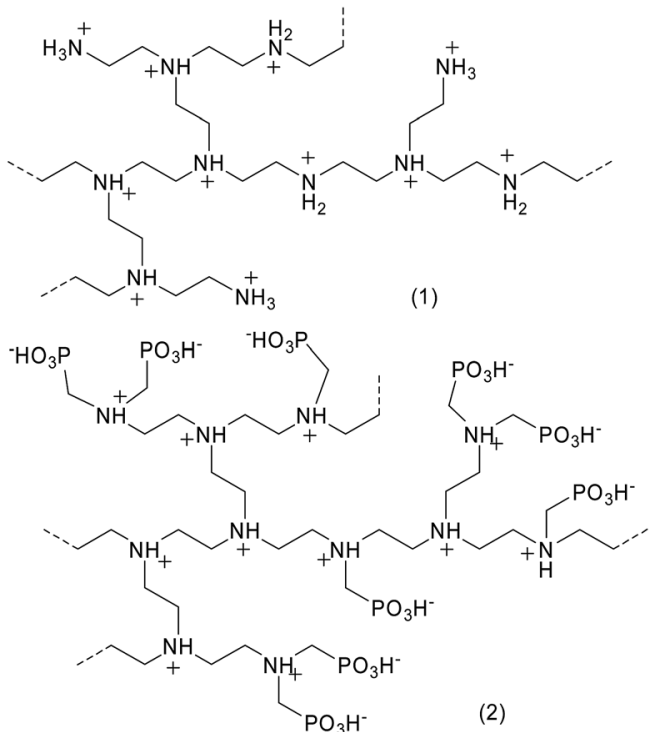<smiles>[CH2-][NH2+]CC(CC)C(C)(C)C</smiles>

(3)<smiles>[X]C1(C)OC(CO)C(OC)C1C(NC(C)=O)C(C)C</smiles><smiles>CC(C)OC1C(CO)OC(C)(C)C(NC[Po](=O)O)C1O</smiles>

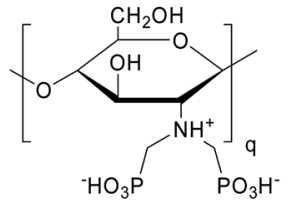

(5)<smiles>CC(O)CO</smiles>

(6)<smiles>CC(C)(C)CC(N1CCCC1=O)C(C)(C)C</smiles>

(7)<smiles>CC(C)(C)CC(N1CCCC1=O)C(C)(C)C</smiles><smiles>CN(C)CCOC(=O)C(C)(C)C(C)(C)CC(C)(C)C</smiles><smiles>CC(C)(C)CC(O)C(C)(C)C</smiles>

(9)
$\mathrm{Na}_{2} \mathrm{SiO}_{3}$

(4)

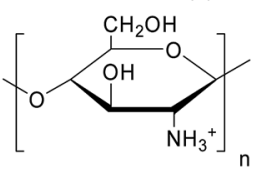

Synergistic combinations of cationic and anionic polymers create in situ supramolecular assemblies that can inhibit the condensation of silicic acid. Condensation in the presence of PEG (1.55-20 kDa, pH 7, without 134 and buffer) gives rise to spherical particles with maximum diameter near $1000 \mathrm{~nm}$ with 6 and $10 \mathrm{kDa}$ samples 
Table 1 (Contd.)

\# $\quad$ Polymer

Poly(allylamine hydrochloride) (1), poly(vinylpyrrolidone) (2), poly(aminoamide) dendrimer of generation 1 (3) and poly(ethyleneimine) (4)<smiles>CCC(CN)C(C)(C)C</smiles><smiles>CC(CN1CCCC1=O)C(C)(C)C</smiles>

(1)

(2)

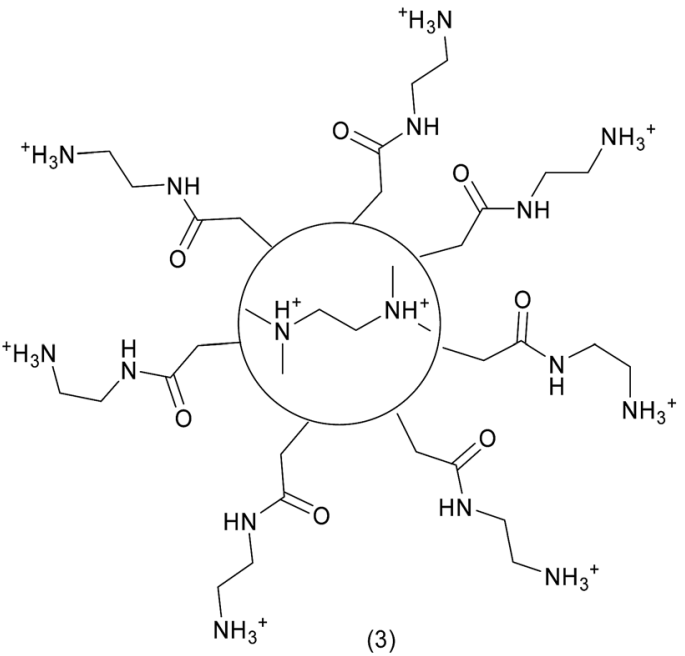<smiles></smiles>

phosphonium-grafted dicationic ethylene oxide bolaamphiphiles, $\mathrm{PEG}^{+}-\mathrm{n}(\mathrm{n}=200,1000,4000)$<smiles>CCC[PH](CCCOCCC(C)(C)O[PH](CCC)(c1ccccc1)c1ccccc1)(c1ccccc1)c1ccccc1</smiles>

Poly(2-methacryloyloxyethyl-co-1-vinylimidazole):

74
Precursor

Brief description of the result

Ref.

$\mathrm{Na}_{2} \mathrm{SiO}_{3}$

The additives accelerate silicic acid polycondensation at $\mathrm{pH} 5.4$ and 7 (without buffer), except for poly(1-vinylpyrrolidone), which shows a minor inhibitory effect

PEGP + -200 showed no influence on condensation at $\mathrm{pH} 7$. In the case of PEGP + -1000, and PEGP + -4000 , it was found that the inhibitory activity is additive dosage-dependent, demonstrating that there is a clear increase in

stabilization ability upon phosphonium PEG dosage increase. The condensation results in spherical particles near $1000 \mathrm{~nm}$

Condensation of silicic acid in the presence of the copolymer results in composite particles containing aggregated or non-aggregated copolymer coils with embedded silica 
Table 1 (Contd.)

\# Polymer

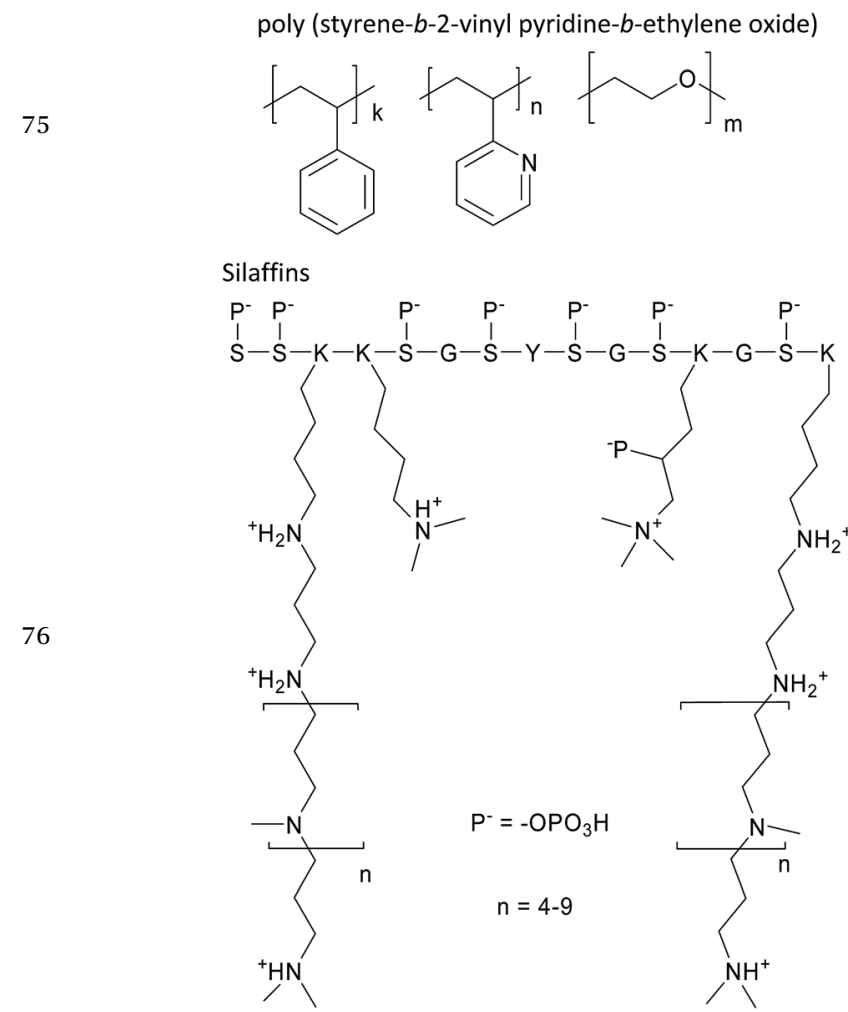

Precursor

Brief description of the result

Ref.

Silicic acid condensation at $\mathrm{pH} 4$ around polymer micelles results in hollow nanoparticles, the average values of the outer diameter, thickness of the shell, and void diameter are 20,6 , and $11 \mathrm{~nm}$, respectively

TMOS

Synthetic model of silaffins

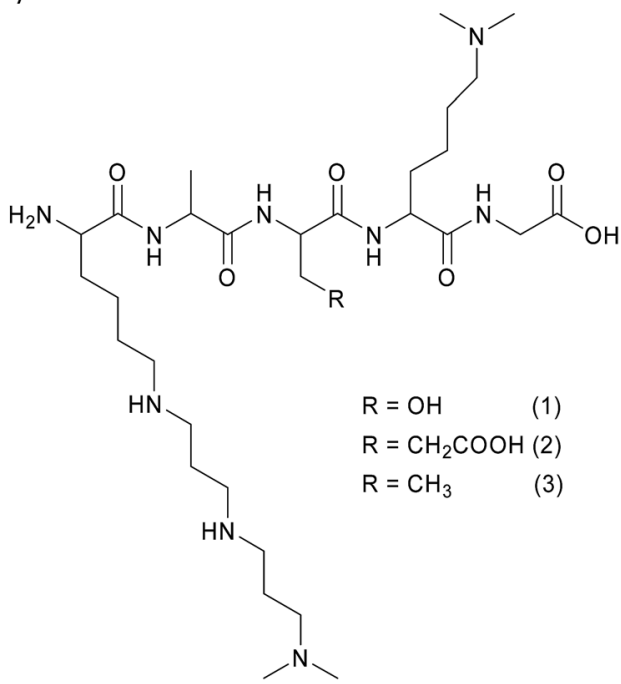

Condensation at $\mathrm{pH} 6.8$

(phosphate buffer) resulted in: 1 silica spheres (hundreds nanometers) and amorphous silica; 2. - few silica spheres but rather grainy silica structures; 3 . silica spheres (hundreds of nanometers)

Poly (allylamine)<smiles>CCC(CN)C(C)(C)C</smiles>

TMOS

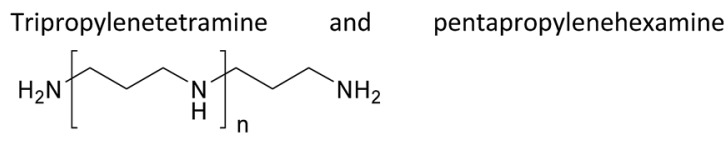

Stable solution of 40-70 nm composite particles was obtained after condensation at pH 6.8 (Tris buffer). Phosphate ions induced formation of spherical particles or hexagonal structures when phosphate was added to the composite nanoparticles

A network of fused silica nanoparticles (diameter around $400 \mathrm{~nm}$ ) is observed at $\mathrm{pH} 7$ (phosphate-citrate buffer) 
Table 1 (Contd.)

\#

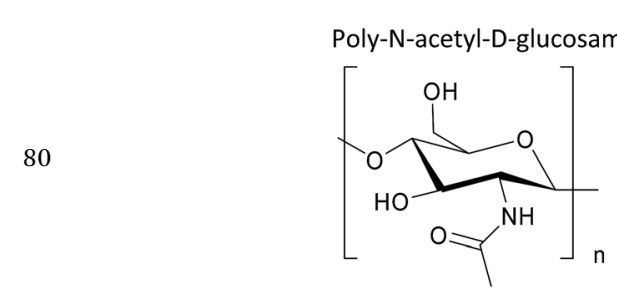

81

Type I collagen

82

Silicatein

Polyamines and native silacidins isolated from diatom Thalassiosira pseudonana

83<smiles>[R]O[R6]=S</smiles>

84

Peptides corresponded to sequences from silaffins:

SKKSGSYSGSKGSKRRIL - R5 (from silaffin- $1 \mathrm{~A}_{1}$ )

SSKKSGSYSGYSTKKSGSRRIL - R2 (from silaffin-1 $\mathrm{A}_{2}$ )

SSKKSGSYYSYGTKKSGSYSGYST - R1 (from silaffin-1B)

SSKKSGSYSGSKGSKRRIL (R5 peptide) and n-AEAEAKAKA

EAEAKAKSSKKSGSYSGSKGSKRRIL-c - EAK-R5 - chimera

consisting of an hydrophobic-polar protein and a silaffin

peptide and demonstrated self assembly into hydrogels

Native sericin (protein from cocoons of the silkworm Bombyx mori). $\mathrm{K}_{2}$-SiKat Polyserine (MW 3000-10 000)

$\mathrm{Na}_{2} \mathrm{SiO}_{3}$

Precursor

Brief description of the result

Ref.

Chitin does not influence silicic acid condensation at pH 5.5 (without buffer) but chitin fibers can be silicified

$\mathrm{K}_{2}$-SiKat waterglass

$\mathrm{Na}_{2} \mathrm{SiO}_{3}$

TMOS

TMOS, $\mathrm{Na}_{2} \mathrm{SiO}_{3}$

TMOS
Low concentrations of a silicate solution promotes fibril formation at pH 7.4 (Tris buffer). The collagen effect on silicic acid condensation was low

$E$. coli was transformed with the silicatein gene. E. coli expressed the silicatein protein which was deposited on the cell surface of the bacteria where it mediates the formation of poly(silicate) after further incubation with monomeric silicic acid

Polyamines do not initiate silica precipitation at $\mathrm{pH} 5.5$ (acetate buffer) but in the presence of acidic peptide silacidin 200 $1500 \mathrm{~nm}$ spherical particles were obtained

Turbidity was found during silicic 69,107 acid condensation in the presence and of the peptides at $\mathrm{pH}$ 7-7.55 150-152 (phosphate and phosphate-citrate buffers) SEM showed 100-300 nm composite particles

R5 and EAK-5 initiate silicification 153 at $\mathrm{pH} 8$ (phosphate buffer) giving rise to hydrogels. Particle size was 80-160 and 300-600 $\mathrm{nm}$ for EAKR5 and 320-700 $\mathrm{nm}$ for R5

The results demonstrate that in aqueous systems, the effect of hydroxyl-containing additives is negligible, although as the molar ratio of the $\mathrm{Si} / \mathrm{OH}$ groups decreases, the effect of these molecules becomes more apparent (some acceleration of the condensation)

Mineralization in the presence of 155 R5 peptide alone gives silica particles with a size distribution of $0.5-10 \mu \mathrm{m}$ in diameter, reactions in the presence of the new fusion proteins generate nanocomposite materials containing silica particles with a narrower size distribution of $0.5-2 \mu \mathrm{m}$ in diameter. The composite morphology and structure could be regulated by controlling processing conditions to produce films and fibers 
Table 1 (Contd.)

\# $\quad$ Polymer

88 Self-assembled $\alpha$-helical fibers from two $\alpha$-helical peptides designed Waterglass to coassemble into a heterodimer. The resulting matured fibers are 50-100 nm thick and tens of micrometers long

R5 peptide and phage peptide clones: SSKKSGSYSGSKGSRRIL - R5 TMOS APPGHHHWHIHH - Si3-3

MSASSYASFSWS - Si3-4

KPSHHHHHTGAN - Si3-8

MSPHPHPRHHHT - Si4-1

MSPHHMHHSHGH - Si4-3

LPHHHHLHTKLP - Si4-7

APHHHHPHHLSR - Si4-8

RGRRRRLSCRLL - Si4-10

TVASNSGLRPAS - Ge4-1

90

Extracts from horsetail Equisetum telmateia

$\mathrm{K}_{2}$-SiKat

Waterglass

$\mathrm{Na}_{2} \mathrm{SiO}_{3}$

Poly(ethyleneoxide)-poly(propyleneoxide)poly(ethyleneoxide) (EO19-PO39-EO19)<smiles>CC(C)OCCC(C)(C)OC(C)CC(C)C(C)OCC(C)(C)C</smiles>

Poly(ethyleneoxide)-poly(propyleneoxide)poly(ethyleneoxide) (EO27-PO61-EO27)<smiles>CC(C)OCCC(C)(C)OCC(C)OC(C)CC(C)(Br)C(C)C</smiles>

Poly(ethyleneoxide)-poly(propyleneoxide)poly(ethyleneoxide) EO2O-PO70-EO20<smiles>CC(C)OCCC(C)(C)OC(C)CC(C)(C)OC(C)C</smiles>

Sodium polymethacrylate
$\mathrm{Na}_{2} \mathrm{SiO}_{3}$

$\mathrm{Na}_{2} \mathrm{SiO}_{3}$

$\mathrm{Na}_{2} \mathrm{SiO}_{3}$

$\mathrm{Na}_{2} \mathrm{SiO}_{3}$
Brief description of the result Ref.

Surface of the fibers is positively 156 charged at $\mathrm{pH} 7.5$ which allows the use of the fibers as matrix for silica formation. Proteolysis removes peptides giving the cleanest preparations of silica nanotubes

R5 peptide gives silica spheres with diameter 500-1000 nm; phage peptide clones form silica nanoparticles with diameter 200 $400 \mathrm{~nm}$
Acceleration of the initial condensation rate at $\mathrm{pH} 7$ in the absence of multiply charged cations, formation of primary $2 \mathrm{~nm}$ siliceous particles.

Silicate of gelatin forms as a flaky, 160-162 white and opaque precipitate, when the solution of silicic acid is gradually added to a solution of gelatin in excess. The precipitate is insoluble in water, and is not decomposed by washing. Silicate of gelatin prepared in the manner described, contains 100 silicic acid to about 92 gelatin units Gelatin activates silica formation 163 at $\mathrm{pH}=5$, alginic acid does not interfere with silica condensation controls silica morphology through the assembly the gelatinsilica aggregates at the microscale Meso-macroporous siliceous materials were prepared using the emulsion template process.

Ibuprofen was immobilized on the material as a model drug

The polymer was used as emulsifier in aqueous medium for octadecane encapsulation into siliceous spherical particles at $\mathrm{pH}$ 2.95-3.05

The polymer was used as emulsifier in aqueous medium for synthesis of siliceous mesocellular 166 foams using hexane as poreforming agent

A mixed solution was dried and dip-coated into $2 \mathrm{M} \mathrm{NH}_{4} \mathrm{HCO}_{3}$ solution giving rise to 167
158 and 


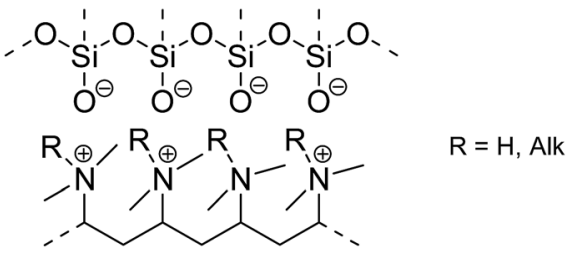

This kind of interaction increases the amount of silanol anions which are active in reaction with unionized monomeric silicic acid and acceleration of $\mathrm{Si}(\mathrm{OH})_{4}$ condensation is observed in neutral and acidic conditions. ${ }^{99,112,118,158,171,172}$

2. Polymers with weak basic groups interact with PSA particles by forming hydrogen bonds. Multiplicity of these interactions enhances binding and decrease in the number of silanol anions as seen in the silicic acid condensation in the presence of poly(1-vinylimidazole) shown below:
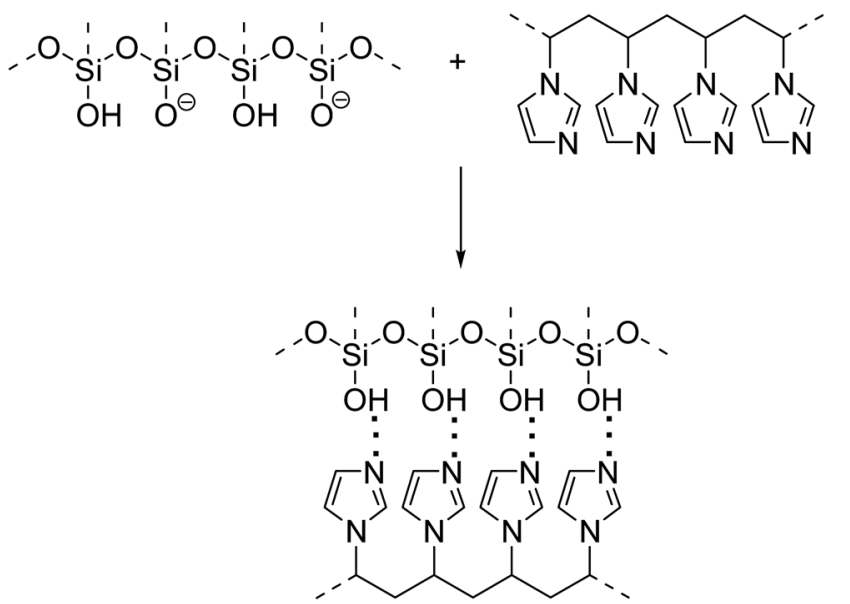

The decrease in $\sim \mathrm{Si}^{-} \mathrm{O}^{-}$concentration results in a decrease in the condensation rate. ${ }^{84,85,102}$ The same effect is probably dominant in the case of poly( $N$-methacryloyl--Lhistidine) ${ }^{102}$ poly(1-vinylpyrrolidone) $)^{136}$ and PEG. ${ }^{134,135,137}$

There is a series of reports which contradict these schemes. ${ }^{131,137,173,174}$ For instance, inhibition of $\mathrm{Si}(\mathrm{OH})_{4}$ condensation is observed for a wide range of polymeric cations and amines. The reason for this contradiction is possibly due to the different procedures employed for measurement of monomeric silicic acid concentration. K. Demadis et al. ${ }^{173}$ have used the silicomolybdate method provided by the HACH Company ${ }^{175}$ which allows the measurement of a "soluble" ("reactive") silica, i.e. short oligomers of unknown length apart from the monomer and dimer molecules. In other reports, ${ }^{124,132-134,176,177}$ the molybdate procedure employed also has variations from the recommended protocol for measuring monomeric and dimeric forms of silicic acid exclusively. ${ }^{56}$ Thus, it appears that the visible inhibition of $\mathrm{Si}(\mathrm{OH})_{4}$ condensation with polycations can be explained by the stabilization of oligomeric forms of PSA through their complexation with polymers that prevents further aggregation of these oligomers. ${ }^{178}$ On the other hand, when a blue molybdenum procedure, elaborated to measure only monomer and dimer of silicic acid is employed, ${ }^{136}$ the same team reported acceleration of the condensation with polymeric bases. These findings imply the importance of the quantification method employed.
The formation of organic polymer - short PSA oligomer complexes also explain dissolution of silica in the presence of polymers capable of interacting with charged silicate species..$^{74,134,179}$ According to our view, the same concepts are involved in the inhibition action of adipic acid/amineterminated polyethers D230/diethylenetriamine copolymer. ${ }^{180}$ This polymer contains many groups capable of forming hydrogen bonds. Moreover, the addition of polyepoxysuccinic acid increases the inhibition, possibly due to neutralization of amine groups in the copolymer. We must also mention that study of the kinetics of $\mathrm{Si}(\mathrm{OH})_{4}$ condensation requires a strict observance of all protocols, including $\mathrm{Si}(\mathrm{OH})_{4}$ preparation from a precursor. For example, in ref. 24 the authors showed that long neutralization of sodium silicate (during $10 \mathrm{~min}$ ) can result in formation of primary PSA oligomers and the system becomes more complex with presence of entities other than the desired silicic acid-polymer.

Most reports devoted to the kinetics of $\mathrm{Si}(\mathrm{OH})_{4}$ condensation in the presence of water-soluble polymers demonstrate the influence of polymers on the condensation rate only and the equilibrium $\mathrm{Si}(\mathrm{OH})_{4}$ concentration was $2-3 \mathrm{mM}$ in the siliceous solutions without additives. These values were also observed as when the condensation proceeded with precipitation of silicapolymer composite. We observed ${ }^{181}$ a decrease of the equilibrium concentration when silicic acid was condensed in the presence of poly(vinyl amine) (PVA) gel containing $\mathrm{Zn}^{2+}$ ions. This gel was able to capture $20 \%$ of silicon from $0.1 \mathrm{mM}$ solution which was attributed to the formation of highly stable PVAPSA complex with participation of zinc ions.

\section{Interaction of polymeric silicic acid with organic polymers in solution}

Condensation of silicic acid in the presence of polymers capable of interacting with PSA results in solutions containing composite nanoparticles or various insoluble products. As mentioned in the earlier sections, PSA-polymer complexes are similar to interpolymer complexes of organic polymers. Interaction between two polymers bearing hydrophilic groups gives rise to so-called stoichiometric or non-stoichiometric complexes. ${ }^{182-184}$ In the first case, all reactive groups, e.g. $\sim \mathrm{COOH}$ and $\sim \mathrm{NH}_{2}$ react with each other and all hydrophilic groups become blocked from interaction with water medium which often results in water insolubility. The nonstoichiometric complexes are obtained when one of the components is in deficiency or when some peculiarities of the main polymeric chains do not allow stoichiometric interaction. The free polymeric segments provide solubility of these complexes. Polyampholytes often gives soluble interpolymeric complexes because only one group (basic or acidic) can interact with another polymer. Both variants are observed in PSA-polymer complexes but siliceous systems differ from organic interpolymer complexes because condensation and/or dissociation reactions can proceed during interaction with organic polymer. Thus, $\mathrm{Si}(\mathrm{OH})_{4}$ condensation in the presence of organic polymer includes several parallel processes: 
1. Silicic acid condensation and growth of siliceous oligomers.

2. Interaction of the siliceous oligomers with organic polymer when the oligomer size will be sufficient for this interaction.

3. Further transformations of the polymer-PSA complex, including sintering of the silica nanoparticles and conformational changes of the organic macromolecules.

Several main factors influence interaction between growing siliceous particles and organic polymers in aqueous medium.

\section{Nature of the polymeric functional groups, $\mathrm{pH}$ and ionic strength}

As mentioned earlier, the ability of the organic polymer to interact with PSA by means of hydrogen and/or ionic bonds depends on the basicity of functional groups. Certainly, $\mathrm{pH}$, ionic strength and temperature must influence this reaction by changing the critical length of the interacting sequences. This effect was observed with polymeric amines. ${ }^{64,90}$ Greater protonation of the amine groups at $\mathrm{pH} 7$ compared with $\mathrm{pH} 9-$ 10 resulted in enhancement of polymer-PSA interactions, larger compaction of the composite nanoparticles in the solution and increase in the precipitation probability. Control of $\mathrm{pH}$ in the reaction medium is often achieved using a buffer. In this case, we must take into account that phosphate, citrate and other multivalent anions influence the silicic acid condensation in the presence of polymeric amines resulting in precipitation of composites. ${ }^{65,71}$ The ability of citrate ion to give aggregates with poly(allylamine) was utilized ${ }^{77}$ to synthesize monodisperse $40-$ $100 \mathrm{~nm}$ composite particles.

\section{Length and flexibility of the polymer chain}

Growth of siliceous particles during silicic acid condensation proceeds at the same time with interaction with organic polymer and depending on the polymer length at least two situations are possible:

1. Polymer chain is long and flexible enough to capture siliceous particle into polymeric coil (Fig. 3A). This results in encapsulation of siliceous particles in organic macromolecules giving rise to soluble composite nanoparticles similar to nonstoichiometric complexes between organic polymers. This behavior was observed for amine containing polymers, ${ }^{112}$
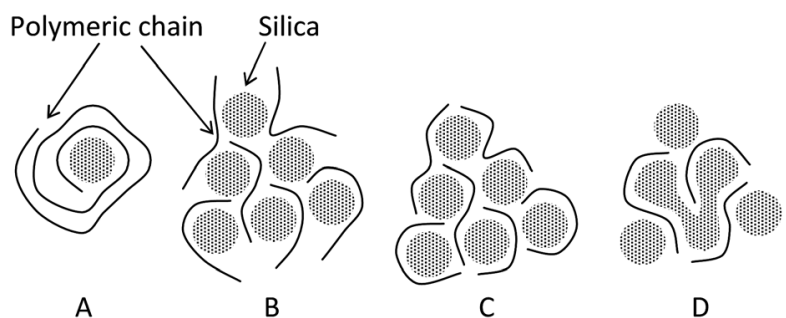

Fig. 3 Schematic representation of different silica-polymer composites. A - long polymeric chain stabilizes siliceous particle; B-D - relatively short polymeric chains which give multiparticle aggregates, soluble $(B)$ or insoluble ( $C$ and $D)$. polymers with imidazole moieties ${ }^{82-84}$ and polyampholytes. ${ }^{85}$ Irrespective of the nature of the functional group and ability of the polymer to accelerate or to inhibit $\mathrm{Si}(\mathrm{OH})_{4}$ condensation, composite soluble nanoparticles can be obtained if the polymer units can interact with $\sim \mathrm{Si}-\mathrm{OH}$ or $\sim \mathrm{Si}^{-} \mathrm{O}^{-}$and the chain is sufficiently long and flexible. Clusters of 50-180 $\mathrm{nm}$ particles built up from regularly sized particles $7-8 \mathrm{~nm}$ in diameter were formed from silicic acid condensation in the presence of horsetail extract (Equisetum telmateia). ${ }^{158}$ Insoluble cellulose macromolecules can also stabilize $4 \mathrm{~nm}$ diameter silica particles. ${ }^{185}$

2. When the polymer chain is relatively short, a single polymer coil can not consume a siliceous particle and various aggregates are formed (Fig. 3B-D). Depending on the nature of the polymer and the reaction conditions, we can obtain large multiparticle aggregates solubilized with free segments of the polymeric chains (Fig. 3B) or insoluble material with siliceous particles serving as cross-linker for the organic polymer (Fig. 3C). In the latter case, further fusion of the siliceous particles is possible when organic polymer is deficient (Fig. 3D).

\section{Polymer : Si ratio}

Interaction between growing PSA nanoparticles and macromolecular chains often results in stable soluble nanoparticles $^{63,64,85,90-93,95,96,115,116,120,131,132}$ or in a product consisting of uniform spherical composite particles. $24,61,62,65-71,75-77,98,99,106-108,111,112,114,117,121,124,134,135,137,139,143,149,153,155,157$ These variants exist in the case of relatively low silicon content in the system, when all PSA nanoparticles can find chains of organic polymer. Further increase in the silicic acid content results in formation of insoluble non-uniform products ${ }^{64,83}$ because of cross-linking by means of silicic acid which was condensed independent of the polymer control.

\section{Biosilicification: how living cell can control silica formation?}

Discovery of silaffins s $^{12,13,140-142}$ - proteins with post-translational phosphate and polyamine modifications (Table 1, \# 73) intensified research focused on investigating silicic acid condensation in the presence of polymeric bases and ampholytes. Silaffins are associated with siliceous frustules of diatoms and the hypothesis of biogenic silica growth around matrix of silaffins was formulated. ${ }^{140,141,143}$ Unfortunately, silaffins can be isolated from diatom frustules in microgram quantities only which is not sufficient for study of their properties including their influence on silicic acid condensation. Hence, synthetic organic polymers can serve as a good model of silaffins. On the other hand, introduction of organic polymers into nonaqueous sol-gel systems is a well-known strategy to obtain interesting composite materials. ${ }^{27,186-188}$ Thus $\mathrm{Si}(\mathrm{OH})_{4}$ condensation regulated by water soluble polymers is expected to result in new bioinspired materials.

On analyzing the reported data on silicic acid-polymer systems (Table 1), we found two peculiarities which distinguish synthetic products from diatom frustules (Fig. 1A and B). The 
precipitates obtained during silicic acid condensation in the presence of organic polymer do not have regular organization at the level of several microns. The usual spherical morphology of these products are often found associated as a continuous structure. The observations of organized structures in some reports ${ }^{\mathbf{1 4 4 , 1 8 9}}$ can be attributed as a sampling artifact because the samples for microscopy were prepared by air-drying of wet precipitates. We showed ${ }^{85}$ that air-drying of composite precipitates can result in self-organization of the particles into highly ordered structures in which the morphology is very distinct from the initial particles precipitated from solution. Selfassociation under slow drying gives highly organized hexagonal lattices from monodisperse 100-200 $\mathrm{nm}$ siliceous particles. ${ }^{97}$ Composite precipitates obtained using an organic polymer contain the polymer in significant amount $(\geq 10 \%)$ but the siliceous frustules of diatoms contain $<5 \%$ of organic compounds, ${ }^{190,191}$ and this organic material are not only from silaffins. Moreover, thorough cleaning of diatom frustules decreases carbon content below $0.2 \% .^{190}$

PSA nanoparticles or oligomers stabilized with biopolymers are the most probable form of silicon in diatoms and similar silicifying organisms. ${ }^{\mathbf{2 4 , 6 4 , 1 4 4}}$ So, a mechanism of conversion of these composite nanoparticles to almost clear silica must exist. This mechanism must be genetically controlled with the object to provide a large diversity of species-specific frustules. A possible mechanism for such control from the cell is desiccation under the action of aquaporines. ${ }^{\mathbf{1 1}}$ This hypothesis includes transport of aquaporines to specified places on the membrane of silica deposition vesicle (SDV) by means of cytoskeleton. SDV contains the precursor of silica (composite nanoparticles) and the aquaporines function as specific pores which pump water out of SDV. Removal of water results in increase of silica precursor concentration which then initiates condensation of soluble composite nanoparticles to solid silica. The question that arises here is: can this desiccation-induced condensation produce silica without large content of organic substances? We have done a model experiment with polyampholyte containing polyamine sidechains. ${ }^{96}$ Desiccation was simulated by centrifugation at $50000 \mathrm{~g}$ which concentrated the composite organo-silica particles at the bottom of the centrifuge tube. We found formation of precipitate from 100-200 nm sintered particles. The precipitate contained $4 \%$ of organic polymer which is closer to biosilica than usual composites obtained from silicic acid and organic polymers. Thus, we hypothesize that silaffins function as stabilizing agents of PSA in diatoms and during desiccation-induced condensation a major part of organic polymer is eliminated from the solid material. A possible scheme of the biosilica synthesis is presented on Fig. 4.

\section{Application areas of the new knowledge in silicic acid condensation}

Study of silicic acid condensation in the presence of watersoluble polymers is related to processes in solution and to formation of solid substances. Both areas provide valuable information for practical applications.
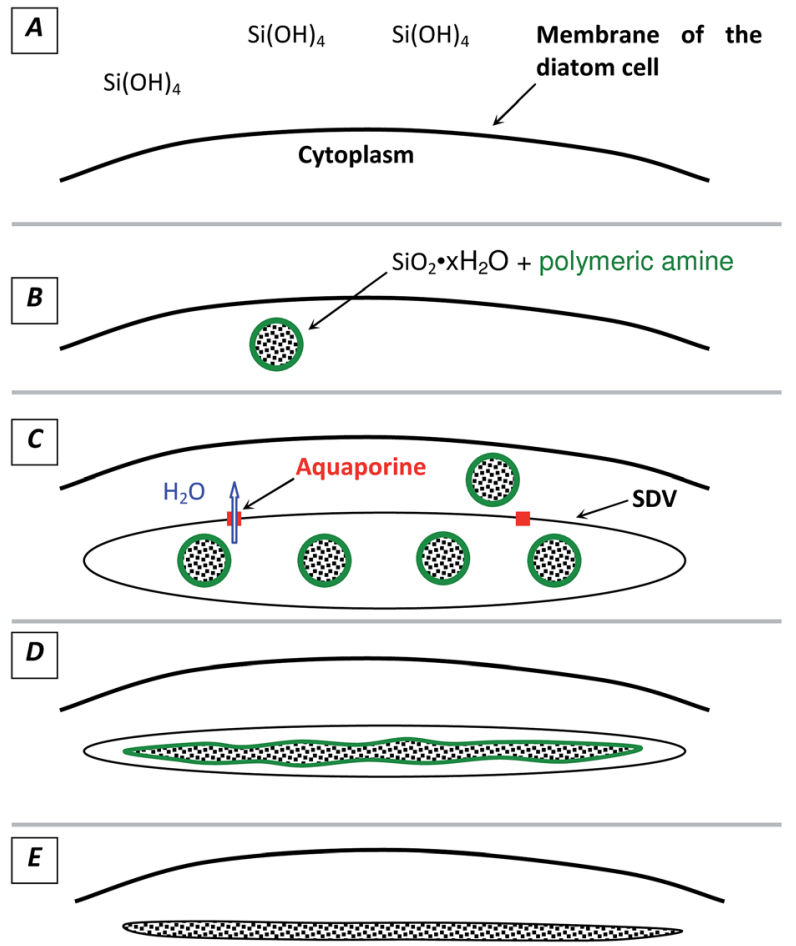

Fig. 4 Scheme of biosilica synthesis in a diatom cell. A - a cell before $\mathrm{Si}(\mathrm{OH})_{4}$ capture from the environment; $\mathrm{B}$ - siliceous nanoparticles stabilized with polymeric shell; C - the siliceous particles are in SDV (Silica Deposition Vesicle) and aquaporines pump water out of SDV; D and $E$ - concentrating-induced condensation and elimination of organic polymer giving rise to solid silica.

The ability of organic polymers to stabilize PSA in an easily hydrolysable form is the basis of water treatment applications. Polymers of silicic acids are the cause of detrimental precipitates in industrial and domestic water flow systems. The addition of various polymers capable of interacting with PSA prevents the precipitation. ${ }^{\mathbf{1 3 1 , 1 3 4 , 1 9 2 - 1 9 4}}$

The soluble composite nanoparticles could be considered as new biomimetic precursors for the synthesis of more complex siliceous structures. These nanoparticles bear negative or positive charge depending on the nature of the organic polymer and can interact with oppositely charged objects. For instance, poly(allyl amine)-based composite nanoparticles formed hexagonal structures when phosphate ions were added to the solution. ${ }^{\mathbf{1 4 4}}$ Positively charged nanoparticles obtained by $\mathrm{Si}(\mathrm{OH})_{4}$ condensation in the presence of poly(vinyl amine) reacted with negative composite nanoparticles obtained with poly(1-vinylimidazole-co-acrylic acid) giving rise to a fibrous material containing $40-50 \%$ of $\mathrm{SiO}_{2}{ }^{64}$

The ability of PSA particles to interact with polymeric amines was employed ${ }^{\mathbf{8 5 , 1 9 5}}$ to create silicified materials by means of direct ink writing with 3D-printers. These studies are based on bioinspired concepts using matrix-assisted condensation of silicic acid.

A major application of silicification in aqueous medium is the encapsulation of biologically active substances, ${ }^{76,95,115,116,120,196}$ including drug delivery. ${ }^{197}$ The 
siliceous shell is usually formed around a complex of polymeric cation and encapsulated moiety, e.g. nucleic acid in transfection applications. The obtained particles with sizes typically below $200 \mathrm{~nm}$ serve as delivery agents, and can release the drug or internalize into the cell following the destruction of the siliceous shell. Silicic acid condensation in the presence of positively charged surfaces opens new vistas for silicification of relatively large objects such as living cells ${ }^{\mathbf{1 0 4 , 1 0 5 , 1 4 8}}$ which retain viability longer than native cells. Islet cell encapsulation in a siliceous layer has been found to be beneficial to extend the survival of the cells. Enzyme encapsulation in siliceous shells is another promising strategy to design highly effective catalysts. Enzymes in free state are homogenous catalysts with disadvantages of low life time, poor stability and large difficulties in separation from the reaction products. Silicic acid condensation in the presence of polymeric bases and enzymes gives rise to particles containing the enzyme $\mathrm{80,100,122}^{\mathbf{8}}$ which retains its catalytic activity. The siliceous layers protect the enzyme from undesirable factors and helps to separate the catalyst from the reaction medium through sedimentation. This approach is protected with an extensive patent. ${ }^{79}$ Particles obtained from silicic acid and polymeric bases can also capture other substances, e.g. soybean oil. ${ }^{123}$

Silicic acid condensation around cationic spherical matrix is a convenient way to obtain hollow particles of various sizes, from hundreds of nanometers to micrometers. The hollow siliceous particles can be applied as containers in drug delivery, as plastic fillers and in design of complex microdevices. Assembly of these particles can commence from organic beads obtained by emulsion polymerization of styrene following with amination of the beads, silicic acid condensation around beads and calcination to remove the organic polymer (Fig. 5A) ${ }^{97,101} \mathrm{~A}$

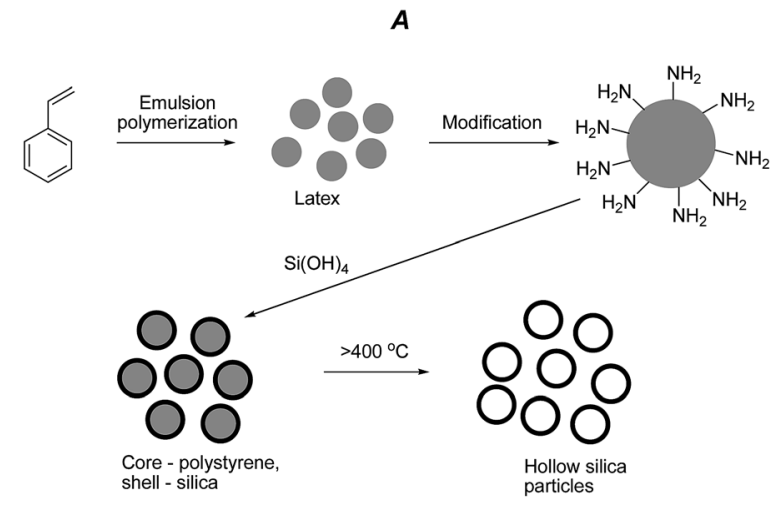

B

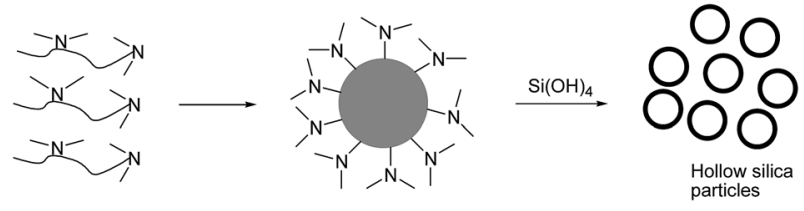

Fig. 5 Schemes of latex-templated synthesis of hollow siliceous particles $(A)$ and silicification on self-organized nano-droplet from low-molecular polyamines (B). solid matrix in the form of porous membrane was applied for synthesis of silica microtubes. ${ }^{\mathbf{1 1 0}}$ The alternative one-step approach to obtain hollow particles involves silicic acid condensation around self-organized low molecular polyamines (Fig. 5B). ${ }^{58}$ The latter method avoids the calcination stage and hence facilitates recycling of the matrix. A similar approach was applied for assembly of core-shell and hollow particles from zein (a major storage protein from corn Zea mays). ${ }^{198}$

Composite submicrometer particles obtained in aqueous medium can be loaded with a fluorescent dye and applied as liquid flow tracers. ${ }^{97}$

The main part of siliceous composite materials is prepared from organic precursors of silicic acid. Sodium silicate is attractive because it is a cheap and ecology-friendly substance comparing to alkoxysilanes. Mesoporous forms of silica based on an amine surfactant as the structure-directing porogen were prepared and used as reinforcing and toughening agents for epoxy polymers. ${ }^{199}$ The material obtained from sodium silicate showed smaller framework pore sizes (4-5 nm) comparing with TEOS-based silica (6-21 nm) and provided exceptional strength and toughness.

Introduction of organic polymers, e.g. poly(ethylene oxide)poly(propylene oxide)-poly(ethylene oxide) triblock copolymer into siliceous gel on the condensation stage results in highly ordered mesoporous structures and pore sizes in the range from 7.5 to $10 \mathrm{~nm}^{.200}$

Silicic acid and its oligomers act as cross-linking agents during polymerization of acrylic acid or acrylamide. ${ }^{201}$ The obtained material can be applied as environmentally-friendly superabsorbent because the crosslinking bonds $\equiv \mathrm{Si}-\mathrm{O}-(\mathrm{O}=)$ $\mathrm{C}$ - are hydrolysable and the sorbent dissolves after several days after application.

Porous materials were obtained by condensation in the presence of $\mathrm{PEG}^{\mathbf{8 8 , 1 6 4}}$ or similar surfactants and emulsifiers such as Span-80 and Tween-80. ${ }^{89}$ Condensation in the presence of water-insoluble substance, e.g. octadecane, results in the substance encapsulation with a smooth and compact silica surface $^{\mathbf{1 6 5}}$ and in the case of hexane siliceous mesocellular foams were obtained. ${ }^{166}$ Organo-silica composites can be applied for synthesis of highly ordered carbon materials by dissolution of silica in hydrofluoric acid. This approach allowed to obtain highly nitrogen doped mesoscopic carbons which show high electrocatalytic activity. ${ }^{202,203}$

\section{Conclusion: future prospects in $\mathrm{Si}(\mathrm{OH})_{4}$-polymer systems}

Silicic acid condensation in the presence of water-soluble polymers is a dynamically developing area and several important points come to the fore:

(a) Development of methods to study silicic acid condensation in solution where the traditional molybdate method must be re-examined and standardized with the objective to ensure that the obtained data correspond to monomeric and dimeric forms of $\mathrm{Si}(\mathrm{OH})_{4}$. This is possible with the use of ${ }^{29} \mathrm{Si} \mathrm{NMR}$ spectrometry and isotope-enriched silicic acid. A promising and 
widely-spread method which allows to distinguish various forms of condensed $\mathrm{Si}(\mathrm{OH})_{4}$ is attenuated total reflection Fourier transform infrared (ATR-FTIR) spectroscopy, including multiple reflection approach. This method requires a special study devoted to the band assignment in water medium in comparison with ${ }^{29} \mathrm{Si}$ NMR data. Soluble nanoparticles formed under silicic acid condensation are difficult systems for study. Light scattering methods are often not sensitive enough for siliceous phase while electron microscopy is complicated and associated with aggregation during sample preparation. So, new approaches are needed in this area, including unusual techniques such as laser ablation combined with aerosol spectrometry. ${ }^{\mathbf{6 4}}$

(b) Simulation of biosilicification where the reaction in aqueous medium is an adequate model to study behavior of silicic acid in living organisms. The accumulated knowledge allows to approach synthesis of artificial silica with structures similar to biogenic silica. On the other hand, mimicking the silica biosynthesis must include simulation of the cell structures participating in this process on a micrometer level, e.g. membranes bearing active domains, because the transition from partially condensed silicic acid coordinated with organic polymer to organized solid silica structures is an important but poorly understood process. The in vitro experiments do not exclude study of living cells like diatoms, sponges, cell cultures of higher organisms. Further progress in this area is expected from coupling of modern equipment with specially designed tracers including fluorescent or spin probes, e.g. tagged silicic acid.

(c) New materials for encapsulation of biologically active compounds into silica or composite particles that opens new possibilities for drug delivery and design of prolonged action preparations. Self-organized water soluble nanoparticles are an attractive option that has emerged from the investigations on silicic acid condensation processes. These particles combine rigidity of siliceous structure with variable functionality of organic polymer. Reversible drying of this nanoparticles is a large challenge for chemists because the presence of active silanol groups provokes aggregation and condensation under usual freeze drying. Elaboration of the novel drying techniques will result in new drug formulations and can solve the problem of the cold chain with preparations containing protein or nucleic acid.

(d) New organic polymers can be developed as further progress in construction of siliceous nanocomposites requires new functional polymers with easily tunable structure, including functionality and the chain length. We can expect involvement of "smart" polymers showing thermo- and $\mathrm{pH}^{-}$ sensitivity for the design of "smart" composites.

\section{Acknowledgements}

We acknowledge financial support from a joint grant of the Russian Science Foundation (\# 16-45-02001) and the Department of Science Technology of the Ministry of Science and Technology of the Republic of India (\# INT/RUS/RSF/10).

\section{Notes and references}

1 C. C. Perry and T. Keeling-Tucker, J. Biol. Inorg Chem., 2000, 5, 537-550.

2 P. Treguer, D. M. Nelson, A. J. Van Bennekom, D. J. Demaster, A. Leynaert and B. Queguiner, Science, 1995, 268, 375-379.

3 R. Gordon, D. Losic, M. A. Tiffany, S. S. Nagy and F. A. S. Sterrenburg, Trends Biotechnol., 2009, 27, 116-127.

4 J. W. Blunt, B. R. Copp, R. A. Keyzers, M. H. G. Munro and M. R. Prinsep, Nat. Prod. Rep., 2013, 30, 237-323.

5 M. J. Uriz, X. Turon, M. A. Becerro and G. Agell, Microsc. Res. Tech., 2003, 62, 279-299.

6 L. E. Datnoff and F. A. Rodrigues, The role of silicon in suppressing rice diseases, APSnet Features, 2005, DOI: 10.1094/APSnetFeature-2005-0205.

7 A. K. da Silva Lobato, E. M. Silva Guedes, D. J. Marques and C. F. de Oliveira Neto, in Responses of organisms to water stress, ed. S. Akinci, InTech, Rijeka, Croatia, 2013, pp. 95113.

8 C. He, L. Wang, X. Liu, J. Ma, Y. Lin and F. Xu, New Phytol., 2013, 200, 700-709.

9 O. Ueno and S. Agarie, Plant Prod. Sci., 2005, 8, 71-73.

10 C. Exley, Front. Plant Sci., 2015, 6, 853.

11 M. A. Grachev, V. V. Annenkov and Y. V. Likhoshway, BioEssays, 2008, 30, 328-337.

12 N. Kroger, R. Deutzmann and M. Sumper, Science, 1999, 286, 1129-1132.

13 N. Kroger, S. Lorenz, E. Brunner and M. Sumper, Science, 2002, 298, 584-586.

14 J. N. Cha, K. Shimizu, Y. Zhou, S. C. Christiansen, B. F. Chmelka, G. D. Stucky and D. E. Morse, Proc. Natl. Acad. Sci. U. S. A., 1999, 96, 361-365.

15 T. Coradin and J. Livage, Acc. Chem. Res., 2007, 40, 819-826.

16 R. Schwarz and W. D. Muller, Z. Anorg. Allg. Chem., 1958, 296, 273-279.

17 I. D. Shcher+ban, Dokl. Akad. Nauk USSR, 1967, 177, 12001203.

18 T. Kotoky and S. K. Dolui, J. Sol-Gel Sci. Technol., 2004, 29, 107-114.

19 R. Iler, The Chemistry of Silica, Wiley, New York, 1982.

20 E. Weitz, H. Franck and M. Schuchard, Chem.-Ztg., 1950, 74, 256-257.

21 R. Schwartz and K. G. Knauff, Z. Anorg. Allg. Chem., 1954, 275, 176-192.

22 D. F. Evans, J. Parr and E. N. Coker, Polyhedron, 1990, 9, 813-823.

23 C. C. Harrison and N. Loton, J. Chem. Soc., Faraday Trans., 1995, 91, 4287-4297.

24 D. Belton, G. Paine, S. V. Patwardhan and C. C. Perry, J. Mater. Chem., 2004, 14, 2231-2241.

25 R. C. Mehrotra and R. P. Narain, Indian J. Chem., 1967, 5, 444-447.

26 M. Meyer, A. Fischer and H. Hoffmann, J. Phys. Chem. B, 2002, 106, 1528-1533. 
27 J. Brinker and G. W. Scherer, Sol-gel science: the physics and chemistry of sol-gel processing, Academic Press, London, 1990.

28 D. J. Belton, O. Deschaume and C. C. Perry, FEBS J., 2012, 279, 1710-1720.

29 T. Tarutani, Anal. Sci., 1989, 5, 245-252.

30 G. R. Choppin, P. Pathak and P. Thakur, Main Group Met. Chem., 2008, 31, 53-72.

31 D. J. Belton, O. Deschaume, S. V. Patwardhan and C. C. Perry, J. Phys. Chem. B, 2010, 114, 9947-9955.

32 J. Tamahrajah and A. Brehm, Mar. Chem., 2016, 181, 18-24.

33 E. R. Pohl and F. D. Osterholtz, in Molecular characterization of composite interfaces, ed. H. Ishida and G. Kumar, Plenum Press, New York, 1985, pp. 157-170.

34 C. G. Swain, R. M. Esteve and R. H. Jones, J. Am. Chem. Soc., 1949, 71, 965-971.

35 W. T. Grubbs and A. Rate, J. Am. Chem. Soc., 1954, 76, 34083414.

36 C. Okkerse, in Physical and chemical aspects of adsorbents and catalysts, ed. B. G. Linsen, Academic Press, London and New York, 1970, pp. 214-264.

37 L. P. Davis and L. W. Burggraf, in Ultrastructure processing of advanced ceramics, ed. J. D. Mackenzie and. D. R. Ulrich, Wiley, New York, 1988, pp. 367-378.

38 E. P. Flint and L. S. Wells, J. Res. Natl. Bur. Stand., 1934, 12, 751-783.

39 P. S. Roller and G. J. Ervin, J. Am. Chem. Soc., 1940, 62, 461471.

40 A. F. Joseph and H. B. Oakley, J. Chem. Soc., 1925, 127, 28132818.

41 W. D. Treadwell and W. Wieland, Helv. Chim. Acta, 1930, 13, 842-864.

42 G. Hagg, Z. Anorg. Allg. Chem., 1926, 155, 21-41.

43 D. R. Lide, CRC Handbook of chemistry and physics, 2009-2010, 90th ed, CRC Press, Boca Raton, 2009.

44 S. Sjöberg, Y. Hägglund, A. Nordin and N. Ingri, Mar. Chem., 1983, 13, 35-44.

45 J. P. Hershey and F. J. Millero, Mar. Chem., 1986, 18, 101105.

46 P. Schindler and H. R. Kamber, Helv. Chim. Acta, 1968, 51, 1781-1786.

47 F. Ordway, Science, 1964, 143, 800-801.

48 P. W. J. G. Wijnen, T. P. M. Beelen and R. A. van Santen, in The colloid chemistry of silica, American Chemical Society, ed. H. E. Bergna, Washington, 1994, pp. 517-531.

49 W. Ostwald, Lehrbuch der Allgemeinen Chemie, Leipzig, Germany, 1896.

50 W. Ostwald, Z. Phys. Chem., 1897, 22, 289-330.

$51 \mathrm{H}$. Jolles and F. Neurath, Angew. Chem., 1898, 11, 315-316. 52 J. D. H. Strickland, J. Am. Chem. Soc., 1952, 74, 862-867.

53 M. Takahashi, Y. Abe and M. Tanaka, Talanta, 2015, 131, 301-308.

54 J. B. Mullen and J. P. Riley, Anal. Chim. Acta, 1955, 12, 162176.

55 R. J. Volk and R. L. Weintraub, Anal. Chem., 1958, 30, 10111014.

56 T. Coradin, D. Eglin and J. Livage, Spectroscopy, 2004, 18, 567-576.
57 X. Yang, P. Roonasi and A. Holmgren, J. Colloid Interface Sci., 2008, 328, 41-47.

58 D. J. Belton, S. V. Patwardhan, V. V. Annenkov, E. N. Danilovtseva and C. C. Perry, Proc. Natl. Acad. Sci. U. S. A., 2008, 105, 5963-5968.

59 V. V. Annenkov, S. V. Patwardhan, D. J. Belton, E. N. Danilovtseva and C. C. Perry, Chem. Commun., 2006, 14, 1521-1523.

60 P. J. Baker, S. V. Patwardhan and K. Numata, Macromol. Biosci., 2014, 14, 1619-1626.

61 N. Kröger, R. Deutzmann, C. Bergsdorf and M. Sumper, Proc. Natl. Acad. Sci. U. S. A., 2000, 97, 14133-14138.

62 M. Sumper, S. Lorenz and E. Brunner, Angew. Chem., Int. Ed., 2003, 42, 5192-5195.

63 V. V. Annenkov, E. N. Danilovtseva, V. O. Aseyev, S. V. Patwardhan and C. C. Perry, in IASTED International Conference on Nanotechnology and Applications, Crete, Greece, 2008.

64 V. V. Annenkov, E. N. Danilovtseva, V. A. Pal'shin, V. O. Aseyev, A. K. Petrov, A. S. Kozlov, S. V. Patwardhan and C. C. Perry, Biomacromolecules, 2011, 12, 1772-1780.

65 E. Brunner, L. Lutz and M. Sumper, Phys. Chem. Chem. Phys., 2004, 6, 854-857.

66 S. V. Patwardhan and S. J. Clarson, Mater. Sci. Eng., C, 2003, 23, 495-499.

67 S. V. Patwardhan and S. J. Clarson, Polym. Bull., 2002, 48, 367-371.

68 S. V. Patwardhan, N. Mukherje and S. J. Clarson, Silicon Chem., 2002, 1, 47-54.

69 S. V. Patwardhan and S. J. Clarson, J. Inorg. Organomet. Polym., 2002, 12, 109-116.

70 S. V. Patwardhan, N. Mukherje and S. J. Clarson, J. Inorg. Organomet. Polym., 2001, 11, 117-121.

71 G. Begum, R. K. Rana, Sh. Singh and L. Satyanarayana, Chem. Mater., 2010, 22, 551-556.

72 V. V. Annenkov, E. N. Danilovtseva and I. N. Kotel'nikov, Polym. Sci., Ser. A, 2008, 50, 147-152.

73 T. Mazutani, H. Nagase, N. Fugiwara and H. Ogoshi, Bull. Chem. Soc. Jpn., 1998, 71, 2017-2022.

74 S. V. Patwardhan, G. E. Tilburey and C. C. Perry, Langmuir, 2011, 27, 15135-15145.

75 S. V. Patwardhan, C. Raab, N. Hüsing and S. J. Clarson, Silicon Chem., 2005, 2, 279-285.

76 S. Davidson, D. A. Lamprou, A. J. Urquhart, M. H. Grant and S. V. Patwardhan, ACS Biomater. Sci. Eng., 2016, 2, 14931503.

77 V. S. Murthy, T. G. Belgard and M. S. Wong, US Pat. 20100222501, 2010.

78 A. Jantschke, K. Spinde and E. Brunner, Beilstein J. Nanotechnol., 2014, 5, 2026-2035.

79 R. Bond, M. C. Jewett, J. C. McAuliffe and D. E. Ward II, US Pat. 7642077, 2010.

80 M. J. Xu, G. M. Gratson, E. B. Duoss, R. F. Shepherd and J. A. Lewis, Soft Matter, 2006, 2, 205-209.

81 P.-X. Zhu and R.-H. Jin, J. Mater. Chem., 2008, 18, 313-318. 
82 M. K. Liang, S. V. Patwardhan, E. N. Danilovtseva, V. V. Annenkov and C. C. Perry, J. Mater. Res., 2009, 24, 1700-1708.

83 V. V. Annenkov, E. N. Danilovtseva, E. A. Filina and Y. V. Likhoshway, J. Polym. Sci., Part A: Polym. Chem., 2006, 44, 820-827.

84 V. V. Annenkov, E. N. Danilovtseva, Y. V. Likhoshway, S. V. Patwardhan and C. C. Perry, J. Mater. Chem., 2008, 18, 553-559.

85 E. N. Danilovtseva, V. A. Pal'shin, Y. V. Likhoshway and V. V. Annenkov, Adv. Sci. Lett., 2011, 4, 616-621.

86 L. N. Yermakova, Yu. G. Frolov, V. A. Kasaikin, A. B. Zezin and V. A. Kabanov, Polym. Sci. U.S.S.R., 1981, 23, 2529-2544.

87 V. Yu. Baranovsky, S. A. Suchishvili, V. A. Kasaikin and V. A. Kabanov, Eur. Polym. J., 1993, 29, 111-114.

88 H. Setyawan, M. Yuwana and R. Balgis, Microporous Mesoporous Mater., 2015, 218, 95-100.

89 Y. P. Bi, C. N. Wu, M. Xin, S. Y. Bi, C. X. Yan, J. F. Hao, F. Li and S. Li, Int. J. Pharm., 2016, 500, 77-84.

90 A. N. Yermakova, P. V. Nuss, V. A. Kasaikin, A. B. Zezin and V. A. Kabanov, Polym. Sci. U.S.S.R., 1983, 25, 1605-1616.

91 R. I. Kalyuzhnaya, Kh. Kh. Khul'chaev, V. A. Kasaikin, A. B. Zezin and V. A. Kabanov, Vysokomol. Soedin., Ser. A Ser. B, 1994, 36, 257-263.

92 L. N. Yermakova, T. A. Aleksandrova, P. V. Nuss, A. M. Vasserman, V. A. Kasaikin, A. B. Zezin and V. A. Kabanov, Polym. Sci. U.S.S.R., 1985, 27, 2073-2080.

93 P. Overton, E. Danilovtseva, E. Karjalainen, M. Karesoja, V. Annenkov, H. Tenhu and V. Aseyev, Polymers, 2016, 8, 96.

94 X. Li, T. Yang, Q. Gao, J. Yuan and Sh. Cheng, J. Colloid Interface Sci., 2009, 338, 99-104.

95 N. Gouda, K. Miyata, R. J. Christie, T. Suma, A. Kishimura, S. Fukushima, T. Nomoto, X. Y. Liu, N. Nishiyama and K. Kataoka, Biomaterials, 2013, 34, 562-570.

96 V. V. Annenkov, V. A. Pal'shin, O. N. Verkhozina, L. I. Larina and E. N. Danilovtseva, Mater. Chem. Phys., 2015, 165, 227234.

97 J. J. L. M. Cornelissen, E. F. Connor, H. C. Kim, V. Y. Lee, T. Magibitang, P. M. Rice, W. Volksen, L. K. Sundberg and R. D. Miller, Chem. Commun., 2003, 8, 1010-1011.

98 E. N. Danilovtseva, V. O. Aseyev, O. Yu. Belozerova, S. N. Zelinskiy and V. V. Annenkov, J. Colloid Interface Sci., 2015, 446, 1-10.

99 Y. M. Jia, G. M. Gray, J. N. Hay, Y. T. Li, G. F. Unali, F. L. Baines and S. P. Armes, J. Mater. Chem., 2005, 15, 2202-2209.

100 R. L. Huang, M. Y. Wu, M. J. Goldman and Z. Li, Biotechnol. Bioeng., 2015, 112, 1092-1101.

101 J. Kim, C. Lee, Y. J. Suh, H. Chang, K. M. Roh and H. D. Jang, Mater. Res. Bull., 2015, 70, 184-189.

102 K. D. Demadis, S. I. Brueckner, E. Brunner, S. Paasch, I. Antonakaki and M. Casolaro, Chem. Mater., 2015, 27, 6827-6836.

103 J. E. Dove, C. M. Shillaber, T. S.Becker, A. F. Wallace and P. M. Dove, J. Geotech. Geoenviron. Eng., 2011, 137, 949-957.

104 S. H. Yang, K. B. Lee, B. Kong, J. H. Kim, H. S. Kim and I. S. Choi, Angew. Chem., Int. Ed., 2009, 48, 9160-9163.
105 J. Desmet, C. Meunier, E. Danloy, M. E. Duprez, F. Lox, D. Thomas, A. L. Hantson, M. Crine, D. Toye, J. Rooke and B. L. Su, J. Colloid Interface Sci., 2015, 448, 79-87.

106 S. V. Patwardhan, N. Mukherjee and S. J. Clarson, J. Inorg. Organomet. Polym., 2001, 11, 193-198.

107 F. Rodriguez, D. D. Glawe, R. R. Naik, K. P. Hallinan and M. O. Stone, Biomacromolecules, 2004, 5, 261-265.

108 M. M. Tomczak, D. D. Glawe, L. F. Drummy, C. G. Lawrence, M. O. Stone, C. C. Perry, D. J. Pochan, T. J. Deming and R. R. Naik, J. Am. Chem. Soc., 2005, 127, 12577-12582.

109 S. V. Patwardhan, N. Mukherjee, M. Steinitz-Kannan and S. J. Clarson, Chem. Commun., 2003, 10, 1122-1123.

110 C. Gautier, P. J. Lopez, J. Livagea and T. Coradin, J. Colloid Interface Sci., 2007, 309, 44-48.

111 S. V. Patwardhan, R. Maheshwari, N. Mukherjee, K. L. Kiick and S. J. Clarson, Biomacromolecules, 2006, 7, 491-497.

112 T. Coradin, O. Durupthy and J. Livage, Langmuir, 2002, 18, 2331-2336.

113 V. S. Murthy, S. B. Kadali and M. S. Wong, ACS Appl. Mater. Interfaces, 2009, 1, 590-596.

114 S. V. Patwardhan and S. J. Clarson, J. Inorg. Organomet. Polym., 2003, 13, 193-203.

115 K. Miyata, N. Gouda, H. Takemoto, M. Oba, Y. Lee, H. Koyama, Y. Yamasaki, K. Itake, N. Nishiyama and K. Kataoka, Biomaterials, 2010, 31, 4764-4770.

116 V. Pandit, A. Watson, L. Ren, A. Mixon and S. P. Kotha, Tissue Eng., Part C, 2015, 21, 786-794.

117 S. V. Patwardhan and S. J. Clarson, J. Inorg. Organomet. Polym., 2003, 13, 49-53.

118 T. Coradin and J. Livage, Colloids Surf., B, 2001, 21, 329336.

119 L. Sheng, H. Chen, W. X. Fu and Z. B. Li, Langmuir, 2015, 31, 11964-11970.

120 S. Kerkhofs, F. Leroux, L. Allouche, R. Mellaerts, J. Jammaer, A. Aerts, C. E. A. Kirschhock, P. C. M. M. Magusin, F. Taulelle, S. Bals, G. Van Tendeloo and J. A. Martens, RSC Adv., 2014, 4, 25650-25657.

121 B. Leng, Zh. Shao, P. H. H. Bomans, L. J. Brylka, N. A. J. M. Sommerdijk, G. de With and W. Ming, Chem. Commun., 2010, 46, 1703-1705.

122 P. P. Luan, Y. J. Jiang, S. P. Zhang, J. Gao, Z. G. Su, G. H. Ma and Y. F. Zhang, J. Biosci. Bioeng., 2014, 118, 575-582.

123 H. Y. Kang and H. H. Chen, J. Food Sci., 2014, 79, E1713E1721.

124 K. D. Demadis, A. Ketsetzi, K. Pachis and V. M. Ramos, Biomacromolecules, 2008, 9, 3288-3293.

$125 \mathrm{Yu}$. A. Shchipunov, T. Yu. Karpenko, I. Yu. Bakunina, Y. V. Burtseva and T. Zvyagintseva, J. Biochem. Biophys. Methods, 2004, 58, 25-38.

$126 \mathrm{Yu}$. A. Shchipunov, Yu. V. Burtseva, T. Yu. Karpenko and N. M. Shevchenko, J. Mol. Catal. B: Enzym., 2006, 40, 16-23.

127 Yu. A. Shchipunov, T. Yu. Karpenko, A. V. Krekoten and I. V. Postnova, J. Colloid Interface Sci., 2005, 287, 373-378.

$128 \mathrm{Yu}$. A. Shchipunov, T. Yu. Karpenko and A. V. Krekoten, Compos. Interfaces, 2005, 11, 587-607. 
129 Yu. A. Shchipunov and T. Yu. Karpenko, Langmuir, 2004, 20, 3882-3887.

130 Yu. A. Shchipunov, J. Colloid Interface Sci., 2003, 268, 68-76.

131 K. D. Demadis and M. Preari, Desalin. Water Treat., 2015, 55, 749-755.

132 K. D. Demadis and A. Stathoulopoulou, Ind. Eng. Chem. Res., 2006, 45, 4436-4440.

133 A. Ketsetzi, A. Stathoulopoulou and K. D. Demadis, Desalination, 2008, 223, 506-512.

134 K. D. Demadis, M. Preari and I. Antonakaki, Pure Appl. Chem., 2014, 86, 1663-1674.

135 M. Preari, K. Spinde, J. Lazic, E. Brunner and K. D. Demadis, J. Am. Chem. Soc., 2014, 136, 4236-4244.

136 K. Spinde, K. Pachis, I. Antonakaki, S. Paasch, E. Brunner and K. D. Demadis, Chem. Mater., 2011, 23, 4676-4687.

137 K. D. Demadis, A. Tsistraki, A. Popa, G. Iliab and A. Visa, RSC Adv., 2012, 2, 631-641.

138 V. V. Annenkov, V. A. Pal'shin and E. N. Danilovtseva, ePolym., 2012, 12, 244-252.

139 A. Khanal, Y. Inoue, M. Yada and K. Nakashima, J. Am. Chem. Soc., 2007, 129, 1534-1535.

140 M. Sumper and N. Kroger, J. Mater. Chem., 2004, 14, 20592065.

141 N. Poulsen, M. Sumper and N. Kroger, Proc. Natl. Acad. Sci. U. S. A., 2003, 100, 12075-12080.

142 N. Kroger, R. Deutzmann and M. Sumper, J. Biol. Chem., 2001, 276, 26066-26070.

143 R. Wieneke, A. Bernecker, R. Riedel, M. Sumper, C. Steinem and A. Geyer, Org. Biomol. Chem., 2011, 9, 5482-5486.

144 M. Sumper, Angew. Chem., Int. Ed., 2004, 43, 2251-2254.

145 F. Noll, M. Sumper and N. Hampp, Nano Lett., 2002, 2, 9195.

146 K. Spinde, M. Kammer, K. Freyer, H. Ehrlich, J. N. Vournakis and E. Brunner, Chem. Mater., 2011, 23, 2973-2978.

147 D. Eglin, K. L. Shafran, J. Livage, T. Coradin and C. C. Perry, J. Mater. Chem., 2006, 16, 4220-4230.

148 W. E. G. Muller, S. Engel, X. H. Wang, S. E. Wolf, W. G. Tremel, N. L. Thakur, A. Krasko, M. Divekar and H. C. Schroder, Biomaterials, 2008, 29, 771-779.

149 S. Wenzl, R. Hett, P. Richthammer and M. Sumper, Angew. Chem., Int. Ed., 2008, 47, 1729-1732.

150 P. W. Whitlock, S. V. Patwardhan, M. O. Stone and S. J. Clarson, in Polymer Biocatalysis and Biomaterials II, ACS Symposium Series, ed. H. N. Cheng and R. A. Gross, 2008, pp. 412-433.

151 R. R. Naik, P. W. Whitlock, F. Rodriguez, L. L. Brott, D. D. Glawe, S. J. Clarson and M. O. Stone, Chem. Commun., 2003, 2, 238-239.

152 L. Senior, M. P. Crump, C. Williams, P. J. Booth, S. Mann, A. W. Perriman and P. Curnow, J. Mater. Chem. B, 2015, 3, 2607-2614.

153 W. D. Marner, A. S. Shaikh, S. J. Muller and J. D. Keasling, Biomacromolecules, 2008, 9, 1-5.

154 G. E. Tilburey, S. V. Patwardhan, J. Huang, D. L. Kaplan and C. C. Perry, J. Phys. Chem. B, 2007, 111, 4630-4638.
155 C. W. Po Foo, S. V. Patwardhan, D. J. Belton, B. Kitchel, D. Anastasiades, J. Huang, R. R. Naik, C. C. Perry and D. L. Kaplan, Proc. Natl. Acad. Sci. U. S. A., 2006, 103, 9428-9433.

156 S. C. Holmstrom, P. J. S. King, M. G. Ryadnov, M. F. Butler, S. Mann and D. N. Woolfson, Langmuir, 2008, 24, 1177811783.

157 R. R. Naik, L. L. Brott, S. J. Clarson and M. O. Stone, J. Nanosci. Nanotechnol., 2002, 2, 95-100.

158 C. C. Perry and T. Keeling-Tucker, Colloid Polym. Sci., 2003, 281, 652-664.

159 C. C. Perry and T. Keeling-Tucker, Chem. Commun., 1998, 23, 2587-2588.

160 T. Graham, J. Chem. Soc., 1862, 15, 216-270.

161 W. J. Lesley, Trans. Faraday Soc., 1930, 26, 69-78.

162 W. J. Lesley, Trans. Faraday Soc., 1929, 25, 570-579.

163 C. Gautier, N. Abdoul-Aribi, C. Rouxa, P. J. Lopez, J. Livage and T. Coradin, Colloids Surf., B, 2008, 65, 140-145.

164 E. Santamaría, A. Maestro, M. Porras, J. M. Gutiérrez and C. González, J. Solid State Chem., 2014, 210, 242-250.

165 F. He, X. Wang and D. Wu, Energy, 2014, 67, 223-233.

166 W. Shan, W. Wang and H. Ru, J. Non-Cryst. Solids, 2015, 425, 183-189.

167 M. Fujiwara, K. Shiokawa, M. Araki, M. Nakao, I. Sakakura and Y. Nakahara, Chem. Eng. J., 2011, 172, 1103-1110.

168 E. Tsuchida and K. Abe, Adv. Polym. Sci., 1982, 45, 15-130.

169 A. Dobry and F. Boyer-Kawenoki, Bull. Soc. Chim. Belg., 1948, 57, 280-285.

170 A. D. Antipina, V. Yu. Baranovskii, I. M. Papisov and V. A. Kabanov, Polym. Sci. U.S.S.R., 1972, 14, 1047-1057.

171 H. Menzel, S. Horstmann, P. Behrens, P. Bärnreuther, I. Krueger and M. Jahns, Chem. Commun., 2003, 24, 29942995.

172 G. M. Gray and J. N. Hay, Mater. Res. Soc. Symp. Proc., 2003, 775, 179-183.

173 K. D. Demadis, J. Chem. Technol. Biotechnol., 2005, 80, 630640.

174 E. Neofotistou and K. D. Demadis, Colloids Surf., A, 2004, 242, 213-216.

175 The Hach Company, Water analysis handbook, The Hach Company, Loveland, Colorado USA, 2004.

176 K. D. Demadis, E. Neofotistou, E. Mavredaki, M. Tsiknakis, E.-M. Sarigiannidou and S. D. Katarachia, Desalination, 2005, 179, 281-295.

177 E. Neofotistou and K. D. Demadis, Desalination, 2004, 167, 257-272.

178 K. D. Demadis and E. Neofotistou, Mater. Perform., 2004, 43, 38-42.

179 L. L. S. Canabady-Rochelle, D. J. Belton, O. Deschaume, H. A. Currie, D. L. Kaplan and C. C. Perry, Biomacromolecules, 2012, 13, 683-690.

180 B. Zhang, S. Xin, Y. Chen and F. Li, J. Colloid Interface Sci., 2012, 368, 181-190.

181 E. Danilovtseva, V. Aseyev, M. Karesoja and V. Annenkov, Eur. Polym. J., 2009, 45, 1391-1396. 
182 M. Pinteala, T. Budtova, V. Epure, N. Belnikevich, V. Harabagiu and B. C. Simionescu, Polymer, 2005, 46, 7047-7054.

183 T. Eishun, O. Yoshihito and S. Kei, J. Polym. Sci., Part A: Polym. Chem., 1972, 10, 3397-3404.

184 A. Shovsky, I. Varga, R. Makuška and P. M. Claesson, Langmuir, 2009, 25, 6113-6121.

185 C. C. Perry and Y. Lu, J. Chem. Soc., Faraday Trans., 1992, 88, 2915-2921.

186 J. Wen and G. L. Wilkes, in Polymeric materials encyclopedia: synthesis, properties, and applications, ed. J. C. Salamone, CRC Press, Boca Raton, 1996, pp. 4782-4792.

187 Y. Chujo, in Polymeric materials encyclopedia: synthesis, properties, and applications, ed J. C. Salamone, CRC Press, Boca Raton, 1996, pp. 4793-4798.

188 J. M. O'Reilly and B. K. Coltrain, in Polymeric materials encyclopedia: synthesis, properties, and applications, ed. J. C. Salamone, CRC Press, Boca Raton, 1996, pp. 4772-4781.

189 M. Sumper and E. Brunner, Adv. Funct. Mater., 2006, 16, 1726.

190 A. E. Ingalls, K. Whitehead and M. C. Bridoux, Geochim. Cosmochim. Acta, 2010, 74, 104-115.

191 W. Jiang, S. Luo, P. Liu, X. Deng, Y. Jing, C. Bai and J. Li, J. Appl. Phycol., 2014, 26, 1511-1518.

192 R. W. Zuhl and Z. Amjad, in Book Mineral Scales in Biological and Industrial Systems, ed. Z. Amjad, CRC Press, 2013, ch. 10, pp. 173-200.
193 M. Preari, and K. D. Demadis, in 13th International Conference of Environmental Science and Technology Athens, Greece, 2013.

194 E. Neofotistou and K. D. Demadis, Int. J. Corros. Scale Inhib., 2014, 3, 28-34.

195 S. H. Yang and I. S. Choi, Chem.-Asian J., 2009, 4, 382-385.

196 T. Coradin, J. Allouche, M. Boissiere and J. Livage, Curr. Nanosci., 2006, 2, 219-230.

197 S. J. P. McInnes and N. H. Voelcker, Future Med. Chem., 2009, 1, 1051-1074.

198 R. J. Baars, Y. M. van Leeuwen, Y. Hendrix, K. P. Velikov, W. K. Kegel and A. P. Philipse, Colloids Surf., A, 2015, 483, 209-215.

199 J. Jiao, X. Sun and T. J. Pinnavaia, Polymer, 2009, 50, 983989.

200 S. H. Joo, R. Ryoo, M. Kruk and M. Jaroniec, J. Phys. Chem. $B, 2002,106,4640-4646$.

201 H. Ye, J.-Q. Zhao and Y.-H. Zhang, J. Appl. Polym. Sci., 2004, 91, 936-940.

202 C. T. Hung, N. Yu, C. T. Chen, P. H. Wu, X. Han, Y. S. Kao, T. C. Liu, Y. Chu, F. Deng, A. Zheng and S. B. Liu, J. Mater. Chem. A, 2014, 2, 20030-20037.

203 J. Lee, J. Kim, Y. Lee, S. Yoon, S. M. Oh and T. Hyeon, Chem. Mater., 2004, 16, 3323-3330. 